
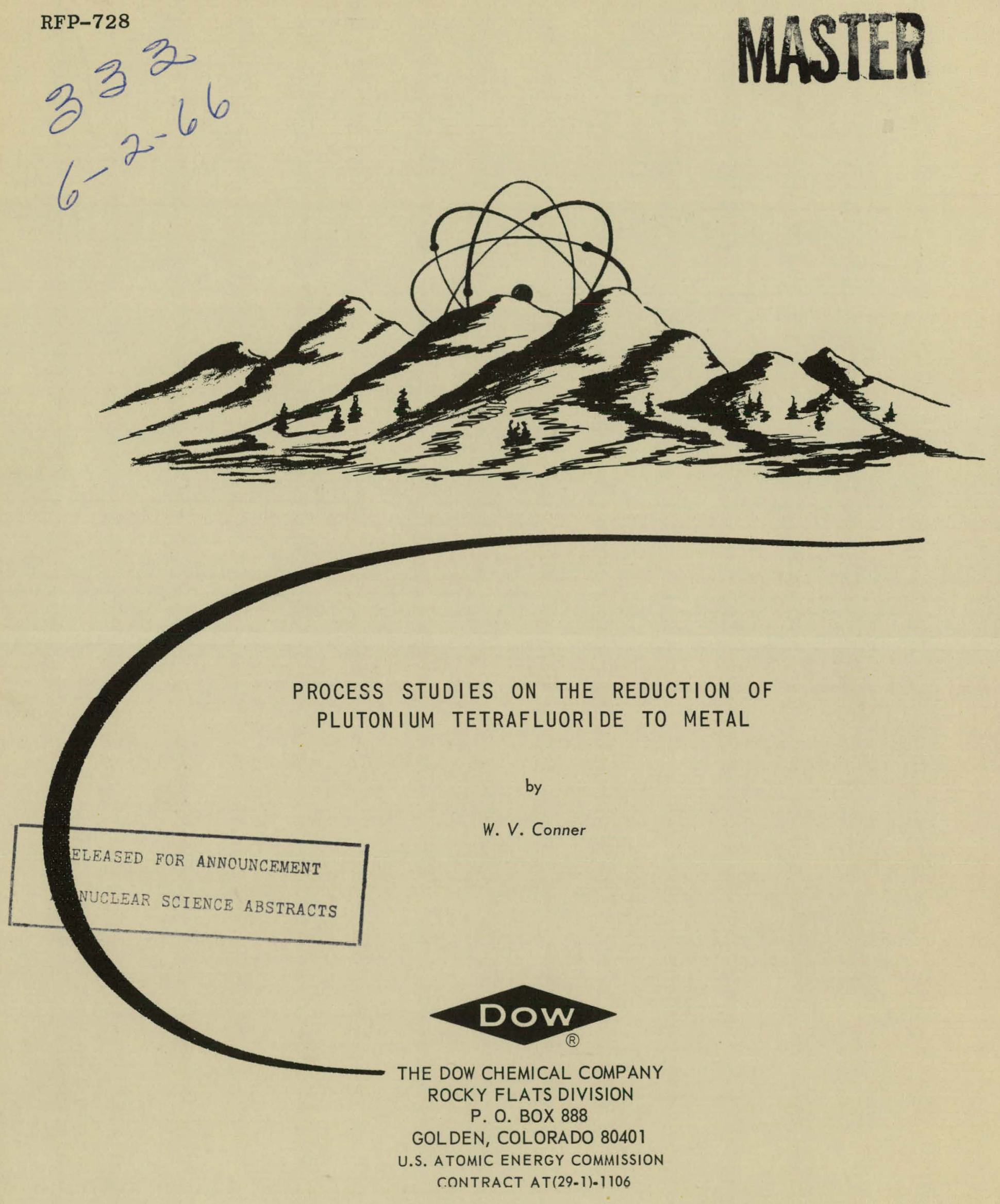


\section{DISCLAIMER}

This report was prepared as an account of work sponsored by an agency of the United States Government. Neither the United States Government nor any agency Thereof, nor any of their employees, makes any warranty, express or implied, or assumes any legal liability or responsibility for the accuracy, completeness, or usefulness of any information, apparatus, product, or process disclosed, or represents that its use would not infringe privately owned rights. Reference herein to any specific commercial product, process, or service by trade name, trademark, manufacturer, or otherwise does not necessarily constitute or imply its endorsement, recommendation, or favoring by the United States Government or any agency thereof. The views and opinions of authors expressed herein do not necessarily state or reflect those of the United States Government or any agency thereof. 


\section{DISCLAIMER}

Portions of this document may be illegible in electronic image products. Images are produced from the best available original document. 


\section{LEG A L NOTICE}

This report was prepared as an account of Government sponsored work. Neither the United States, nor the Commission, nor any person acting on behalf of the Commission:

A. Makes any warranty or representation, expressed or implied, with respect to the accuracy, completeness, or usefulness of the information contained in this report, or that the use of any information, apparatus, method, or process disclosed in this report may not infringe privately owned rights; or

B. Assumes any liabilities with respect to the use of, or for damages resulting from the use of any information, apparatus, method, or process disclosed in this report.

As used in the above, "person acting on behalf of the Commission" includes any employee or contractor of the Commission, or employee of such contractor, to the extent that such employee or contractor of the Commission, or employee of such contractor prepares, disseminates, or provides access to, any information pursuant to his employment or contract with the Commission, or his employment with such contractor.

Printed in USA. Price $\$ 2$. Available from the Clearinghouse for Federal Scientific and Technical Information, National Bureau of Standards,

U. S. Department of Commerce, Springfield, Virginia 
CFSTI PRICES

RELEASED FOR ANNOUNCEMENT

IN NUCEEAR SCIENCE ABSTRACTS
H. $\$ 2.00 \mathrm{MN}=50$

\title{
PROCESS STUDIES ON THE REDUCTION OF PLUTONIUM TETRAFLUORIDE TO METAL
}

\author{
by
}

W. V. Conner

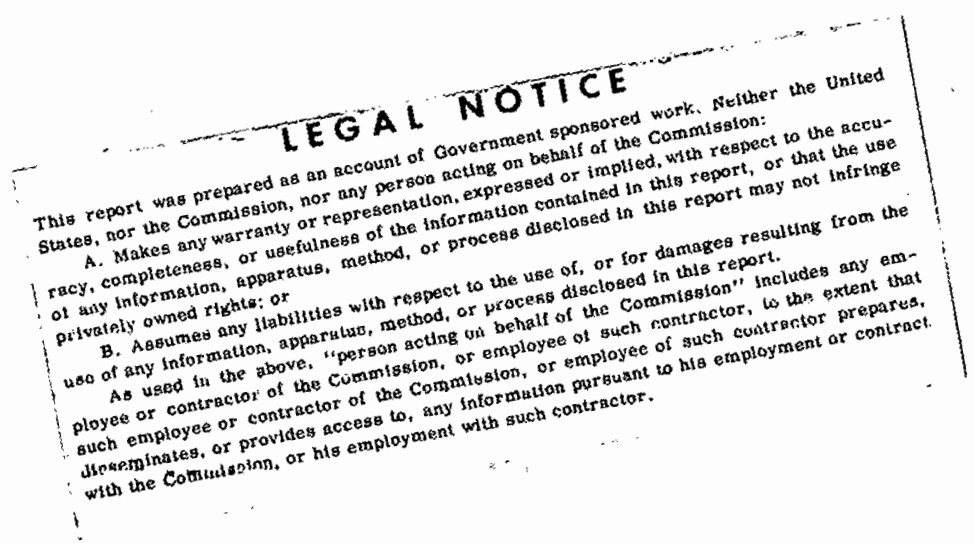

THE DOW CHEMICAL COMPANY ROCKY FLATS DIVISION

P. O. BOX 888

GOLDEN, COLORADO 80401

U.S. ATOMIC ENERGY COMMISSION CONTRACT AT(29-1).1106 
The author wishes to express his gratitude to B. D. Troyer who gathered some of the dato used in the reduction yield study, and to R. L. Smith who assisted the author in collecting the rest of the data presented in this report. 


\section{CONTENTS}

Page No.

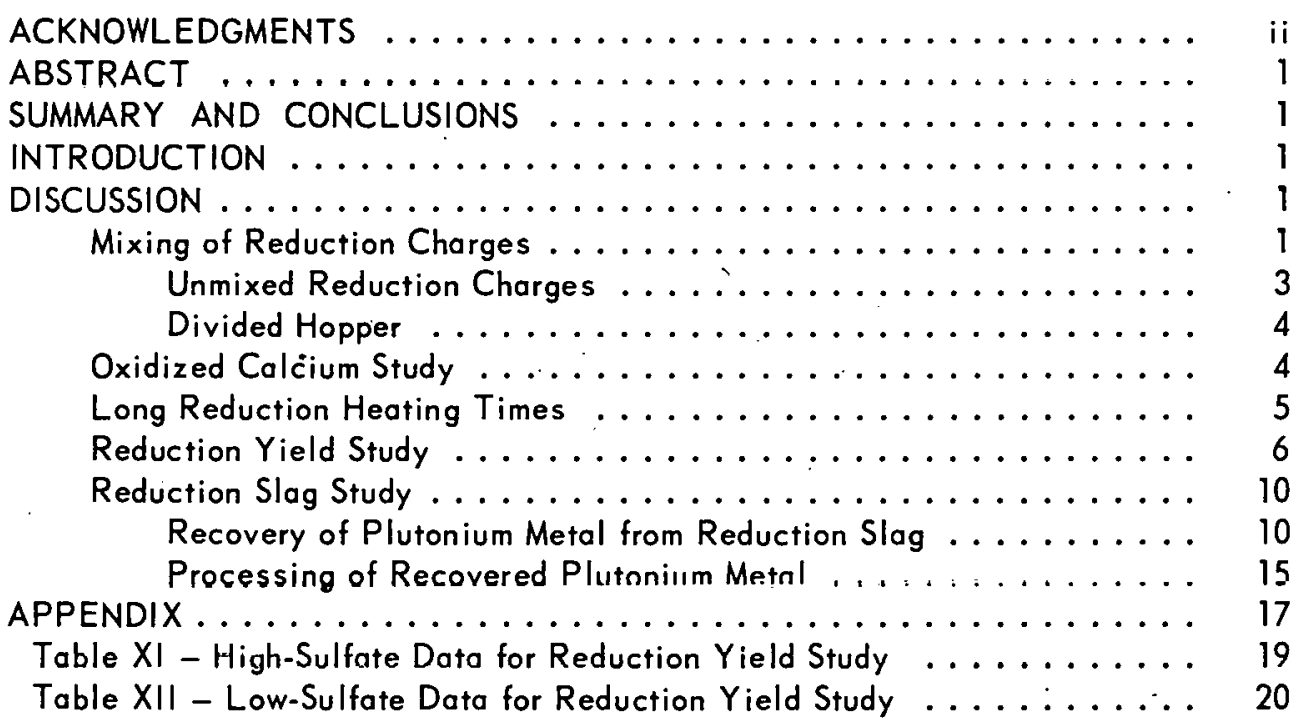


RFP-728

IV 
Several studies were conducted on the factors which will affect the reduction of plutonium tetrafluoride to plutonium metal using calcium as the reductant. The results of these studies are presented in this report.

\section{SUMMARY AND CONCLUSIONS-}

It was found that the degree to which the calcium and plutonium tetrafuoride reactants are mixed has no affect on the reduction yield. The location of the plutonium tetrafluoride does, however, affect the reduction yield. A good metal yield can be obtained from an unmixed charge if the plutonium tetrafuoride is placed on top of the calcium. If, however, the plutonium tetrafluoride is placed in the bottom of the reaction vessel, a poor metal yield will result. It is possible to eliminate the problem of the reduction charge being prepared with plutonium tetrafluoride. in the bottom of the reaction vessel by using a divided hopper to prepared the charge.

It was found as a result of one of the studies that a good correlation exists between the chemical composition of the plutonium tetrafluoride used in a reduction charge and the reduction yield.

The slags from low yield reductions were found to contain pieces of plutonium metal which were large enough to recover from the slag. It was also found that this recovered metal could be processed by adding it to a normal reduction charge.

\section{INTRODUCTION}

The final step in the process for recovering plutonium at the Rocky Flats Plant which is operated for the AEC by The Dow Chemical Company, is the reduction of plutonium tetrafluoride to plutonium metal using calcium as the reductant. The metal yield which is obtained from this step is sometimes quite low. A series of studies were conducted in an attempt to determine the cause or causes of these low yields. It was hoped that this information could be used to modify or control the reaction conditions and eliminate these low yields. The results of these studies are presented in this report.

\section{DISCUSSION}

The procedure (at Rocky Flats) for reducing plutonium tetrafluoride to plutonium metal is similar to the procedure which is used at other plutonium producing facilities in the United States. (1) The plutonium tetrafluoride is mixed with calcium metal and this mixture is placed in a preed reaction vessel. The reaction vessel is then placed

(1) Conner, W. V., Reduction of Plutonium Compounds to Plutonium Metal, The Dow Chemical Company, Rocky Flats Division, Februory 7, 1964, RFP-356 in an induction furnace and heated until the reaction temperature is reached. It should be stated here that what is referred to as plutonium tetrafluoride in this report is not pure plutonium tetrafluoride, but a mixture of plutonium tetrafluoride and plutonium oxide which may contain some impurities such as sulfate or nitrate.

The reaction vessel consists of a magnesium oxide crucible which is placed within a stainless-steel pressure vessel. The annulus between the crucible and pressure vessel is filled with magnesium oxide sand and a crucible lid is placed on the crucible. A copper gasket is placed in a groove around the top of the pressure vessel and the prepared reaction vessel is ready to be placed in an induction furnace.

It has been assumed that thorough mixing of the reactants is important if a good reaction is to be obtained. It was felt, therefore, that variations in operator mixing technique could have an effect on the reduction. Because of this a study was conducted to determine the degree to which variations in charge-mixing offect the reduction.

\section{MIXING OF REDUCTION CHARGES}

The first charges for this study were prepared by placing one-half of the calcium in the bottom of the 
reaction vessel. The other half of the calcium was mixed with a portion of the plutonium tetrafluoride and this, mixture was placed on top of the calcium. The rest of the plutonium tetrafluoride was placed on top of the mixture. The data given in Table 1 for runs No. 1,2 and 3 show that varying the amount of plutonium tetrafluoride which was mixed with calcium did not affect the reduction yield.

The next two runs, No. 4 and 5, were made with the charges unmixed. All of the calcium was placed in the bottom of the reaction vessel and all the plutonium tetrafluoride was placed on top of the calcium. Although the charge for run No. 4 did not react, the charge for run No. 5 reacted and produced a good metal yield.

The charges for the last four runs, No. 6-9 shown in Table I, were prepared in pairs by mixing two batches of plutonium tetrafluoride and then spliting the mixture into two portions. One of the charges from the mixture was prepared with the plutonium tetrafluoride and calcium well mixed. The other charge from the mixture was prepared by placing one-fourth of the plutonium tetrafluoride in the bottom of the reaction vessel and mixing the rest of the plutonium tetrafluoride with the calcium and placing this mixture on top of the plutonium tetrafluoride. As the data in Table I show, the

TABLE I

CHEMICAL AND REDUCTION DATA FOR MIXING STUDY

\begin{tabular}{|c|c|c|c|c|c|c|c|c|c|c|c|c|}
\hline \multirow{2}{*}{$\begin{array}{l}\text { Run } \\
\text { No. }\end{array}$} & \multirow{2}{*}{$\begin{array}{l}\text { Heating } \\
\text { Time, } \\
\text { min. } \\
\end{array}$} & \multirow{2}{*}{$\begin{array}{l}\text { Charge } \\
\mathrm{PuF}_{4}\end{array}$} & \multirow{2}{*}{$\frac{\text { Welght, }}{\text { P.u }}$} & \multirow{2}{*}{$\frac{\text { grams }}{\mathrm{Ca}}$} & \multirow{2}{*}{$\begin{array}{l}\text { Button } \\
\text { Weight, } \\
\text { grams } \\
\end{array}$} & \multirow{2}{*}{$\begin{array}{c}\text { Yield } \\
\% \\
\end{array}$} & \multicolumn{5}{|c|}{ Chemical Composition of $\mathrm{PuF}_{4}, \%$} & \multirow[b]{2}{*}{ Mixing } \\
\hline & & & & & & & $\mathrm{Pi}$ & $F$ & $\mathrm{SO}_{4}$ & $\mathrm{NO}_{3}$ & $\mathrm{PuO}_{2}$ & \\
\hline 1 & 49 & 1990 & 1549 & 665 & 1440 & 93 & 77.85 & 18.71 & 0.35 & 0.08 & - & $\begin{array}{l}1 / 2 \mathrm{Ca} \text { on bottom } \\
1 / 2 \mathrm{Ca} \text { mixed with } \\
3 / 4 \mathrm{PuF}_{4} \\
1 / 4 \mathrm{PuF}_{4} \text { on top }\end{array}$ \\
\hline 2 & 34 & 1926 & 1502 & 645 & 1457 & 97 & 77.98 & 19.0 & 0.55 & 0.13 & - & $\begin{array}{l}1 / 2 \text { Ca on bottom } \\
1 / 2 \text { Ca mixed with } \\
1 / 2 \mathrm{PuF}_{4} \\
1 / 2 \mathrm{PuF}_{4} \text { on top }\end{array}$ \\
\hline 3 & 54 & 1985 & 1539 & 664 & 1479 & 96.1 & 77.53 & 20.62 & 0.5 & 0.08 & - & $\begin{array}{l}1 / 2 \text { Ca on bottom } \\
1 / 2 \text { Ca mixed with } \\
1 / 4 \mathrm{PuF}_{4} \\
3 / 4 \mathrm{PuF}_{4} \text { on top }\end{array}$ \\
\hline 4 & $\begin{array}{l}\text { did } \\
\text { not } \\
\text { fire }\end{array}$ & 2038 & 1559 & 680 & - & - & 76.52 & 22.9 & 0.34 & $<0.04$ & - & $\begin{array}{l}\mathrm{Ca} \text { and } \mathrm{PuF}_{4} \text { unmixed } \\
\mathrm{Ca} \text { on bottom } \\
\mathrm{PuF}_{4} \text { on top }\end{array}$ \\
\hline 5 & 63 & 1988 & 1521 & 664 & 1492 & 98.1 & 76.51 & 22.4 & $<0.1$ & $<0.04$ & 4.5 & $\begin{array}{l}\text { Ca and } \mathrm{PuF}_{4} \text { unmixed } \\
\mathrm{Ca} \text { on bottom } \\
\mathrm{PuF}_{4} \text { on top }\end{array}$ \\
\hline $6^{\star}$ & 43 & 1988 & 1522 & 664 & 1475 & 96.9 & 76.54 & 22.2 & $<0.1$ & $<0.04$ & 4.0 & $\begin{array}{l}\mathrm{Ca} \text { and } \mathrm{PuF}_{4} \text { well } \\
\text { mixed }\end{array}$ \\
\hline 7 & 33 & 2171 & 1676 & 723 & 1370 & 81.7. & 77.2 & 20.5 & $<0.1$ & $<0.04$ & 10.2 & $\begin{array}{l}1 / 4 \mathrm{PuF}_{4} \text { on bottom } \\
\text { All Co and } 3 / 4 \mathrm{PuF}_{4} \\
\text { on top and mixed }\end{array}$ \\
\hline $8^{k x}$ & 50 & 2171 & 1680 & 723 & 1616 & 96.2 & 77.37 & 20.4 & $<0.1$ & $<0.04$ & 12.5 & $\begin{array}{l}\mathrm{Co}_{0} \text { and } \mathrm{PuF}_{4} \text { well } \\
\text { mixed }\end{array}$ \\
\hline 9 & 27 & 2171 & 1678 & 723 & 1478 & 88.1 & 77.3 & 20.0 & 0.51 & $<0.04$ & 15.0 & $\begin{array}{l}1 / 4 \mathrm{PuF}_{4} \text { on botte- } \\
\text { All } \mathrm{Ca} \text { and } 3 / 4 \mathrm{Pl} \\
\text { on top and mixed }\end{array}$ \\
\hline
\end{tabular}

* Control batch for run No. 7 (two botches of $\mathrm{PuF}_{4}$ mixed and split for runs No. 6 and 7 ).

$\star \star$ Control bateh for run No. 9. 
charges which were prepared with plutonium tetrafluoride in the bottom of the reaction vessel gave very poor metal yields. The probable reason for these low yields is that the calcium, being less dense than the plutonium tetrafluoride and the reaction products, moved toward the top of the charge when the reaction took place. The plutonium tetrafluoride in the bottom of the vessel did not come in contact with the calcium and therefore did not react.

\section{Unmixed Reduction Charges}

It was felt that some of the very low reduction yields which occur in the course of normal production operations could be caused by plutonium tetrafluoride being placed in the bottom of the reaction vessels when the charges were prepared. Because of this, a series of reductions were made with unmixed charges, calcium on the bottom and plutonium tetrafluoride on top, to determine if this method of charge preparation could be used on a production basis. A total of 13 reductions were made with the charges unmixed, and 11 of these charges reacted and 2 did not. The 11 charges which did react produced metal yields which were good for the quality of plutonium tetrafluoride which was used, see Table II. It was felt, however, that the number of charges which did not react (15 percent) was too high for this method of charge preparation to be used on a production basis.

When the three charges mentioned, run No. 4 in Table $I$ and runs No. 8 and 13 in Table II, did not react, the calcium was separated from the plutonium tetrafluoride and new charges were prepared by mixing new calcium with the plutonium tetrafluoride. In all three cases the new charges reacted and produced good metal yields.

When the calcium from the charges which did not react was examined, the calcium which had been in contact with the plutonium tetrafluoride was found to be coated with a dark colored material. Samples of this calcium were submitted to the laboratory for analysis, and the coating was found to be calcium fluoride. The plutonium tetrafluoride produced at Rocky Flats is known to have hydrogen fluoride (2) absorbed on its surface.

When samples of the plutonium tetrafluoride from the unreacted charges were submitted to the laboratory for analysis, it was found that the samples of plutonium tetrafluoride which had been in contact with the calcium contained less hydrogen fluoride than the samples of plutonium tetrafluoride which had not been in contact with the calcium.

It is felt, then, that the three charges failed to react because of coating of the calcium at the interface between the calcium and plutonium tetrafluoride. It is felt that the calcium reacted with the hydrogen fluoride which was absorbed on the surface of the tetrafluoride and became coated with calcium fluoride before the reaction temperature was reached. It is possible that unmixed charges

(2) Conner, W. V., Gasket.Failures in Plutonium Reduction Furnaces, The Dow Chemical Company, Rocky Flats Division, October 28, 1964, RFP-435.

\section{TABLE II}

\section{CHEMICAL AND REOUCTION DATA FOR UNMIXED CHARGES}

\begin{tabular}{|c|c|c|c|}
\hline \multicolumn{4}{|l|}{ Heating } \\
\hline min. & $\mathrm{PuF}_{4}$ & $\mathrm{Pu}$ & $\bar{C}$ \\
\hline 27 & 2079 & 1613 & \\
\hline 26 & 2066 & 1585 & \\
\hline 38 & 2165 & 1676 & \\
\hline 41 & 2138 & 1659 & 7 \\
\hline 43 & 2131 & 1666 & 7 \\
\hline 33 & 2148 & 1665 & 7 \\
\hline 33 & 2155 & 1681 & 7 \\
\hline did not fire & 2171 & 1690 & 71 \\
\hline 60 & 2171 & 1680 & 7 \\
\hline 29 & 2175 & 1685 & 71 \\
\hline 26 & 2171 & 1685 & \\
\hline 33 & 2171 & $1689^{\circ}$ & \\
\hline did nọt fire & 2171 & 1686 & \\
\hline
\end{tabular}

\begin{tabular}{c} 
Button \\
Weight \\
grams \\
\hline 1557 \\
1532 \\
1581 \\
1289 \\
1545 \\
1563 \\
1403 \\
- \\
1614 \\
1529 \\
1638 \\
1607 \\
-
\end{tabular}

\begin{tabular}{c}
$\begin{array}{c}\text { Yield } \\
\%\end{array}$ \\
\hline$\frac{96.5}{96.5}$ \\
94.3 \\
77.7 \\
92.7 \\
93.9 \\
83.5 \\
- \\
96.1 \\
90.7 \\
97.2 \\
95.1 \\
-
\end{tabular}

\begin{tabular}{|c|c|c|c|c|}
\hline \multicolumn{5}{|c|}{ Chemical Composition of $\mathrm{PuF}_{1}, \%$} \\
\hline$\overline{P u}$ & $F$ & $\mathrm{SO}_{4}$ & $\mathrm{NO}_{3}$ & $\overline{\mathrm{PuO}_{2}}$ \\
\hline 77.60 & 19.99 & 0.36 & $<0.04$ & - \\
\hline 76.73 & 20.7 & 0.68 & 0.06 & 8.2 \\
\hline 77.39 & 19.31 & 1.86 & 0.07 & 15.5 \\
\hline 77.58 & 17.9 & 0.75 & $<0.04$ & 17.7 \\
\hline 78.15 & 18.9 & $<0.2$ & $<0.04$ & 15.0 \\
\hline 77.49 & 19.0 & 0.58 & $<0.04$ & 16.3 \\
\hline 78.0 & 18.8 & $<0.2$ & $<0.04$ & 16.6 \\
\hline 77.87 & 19.1 & $<0.2$ & $<0.04$ & 12.7 \\
\hline 77.35 & 21.1 & 0.46 & $<0.04$ & 4.0 \\
\hline 77.46 & 19.84 & $<0.2$ & $<0.04$ & 11.4 \\
\hline 77.55 & 19.3 & 0.36 & $<0.04$ & 9.6 \\
\hline 77.80 & 19.0 & $<0.2$ & $<0.04$ & 14.7 \\
\hline 77.67 & 19.4 & $<0.2$ & $<0.04$ & 11.4 \\
\hline
\end{tabular}


could be used on a production basis if a suitable method could be found to initiate the reaction before this coating occurred.

It can be said, then, that the order in which the reactants are placed in the reaction vessel does have an effect on the reduction yield, but the degree to which they are mixed does not. If the reactants are placed in the vessel with plutonium tetrafluoride on the bottom, the metal yield will be low. If, however, the reactants are placed in the vessel with calcium on the bottom, they do not have to be mixed to obtain a good metal yield if the charge reacts. Since 15 percent of the charges did not react, however, this method of charge preparation should not be used on a production basis.

\section{Divided Hopper}

When it was determined that the unmixed charges should not be used on a production basis, several reduction charges were prepared in the divided hopper shown in Figure 1. The charges were prepared by first placing the calcium in one side of the hopper and then placing the plutonium tetrafluoride in the other side of the hopper.

A portion of the calcium filled the space between the divider and the sliding gate, and this eliminated the possibility of the charge being prepared with plutonium tetrafluoride in the bottom of the reaction vessel. The mixing which was achieved by the simultaneous flow of calcium and plutonium tetrafluoride into the reaction vessel was sufficient to provide enough calcium surface in contact with the tetrafluoride to keep the calcium coating from becoming a problem.

The divided hopper was first used to prepare seven test reductions. The data obtained from these reductions (see Table III) show that, with the

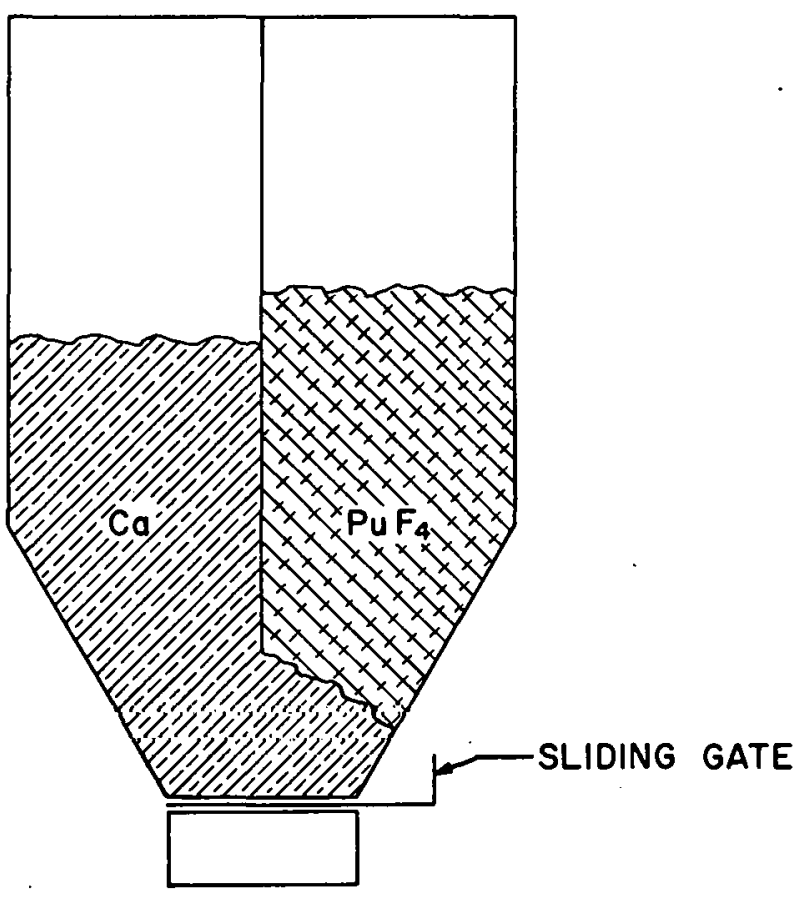

Figure 1. DIVIDED HOPPER

exception of runs No. 4 and 5, the charges prepared in the divided hopper produced good metal yields. The low yields for runs No. 4 and 5 were caused by the formation of large amounts of plutonium oxyfluoride in the reduction slag. It is felt that the formation of the plutonium oxyfluoride was in no way caused by using the divided hopper, because the oxyfluoride has been found in slags from several reductions prepared in the normal manner. Also, several additional reductions were made using the divided hopper and they produced good metal yields.

\section{OXIDIZED CALCIUM STUDY}

The calcium which is used in the reduction of plutonium tetrafluoride at Rocky Flats is purchased in

TABLE III

CHEMICAL AND REDUCTION DATA FOR CHARGES PREPARED IN DIVIDED HOPPER

Hearing

\begin{tabular}{l} 
Run \\
No. \\
\hline 1 \\
2 \\
3 \\
4 \\
5 \\
6 \\
7
\end{tabular}

Time,

\begin{tabular}{c} 
min. \\
\hline 30 \\
42 \\
36 \\
52 \\
35 \\
33 \\
30
\end{tabular}

Charge Weight, grams

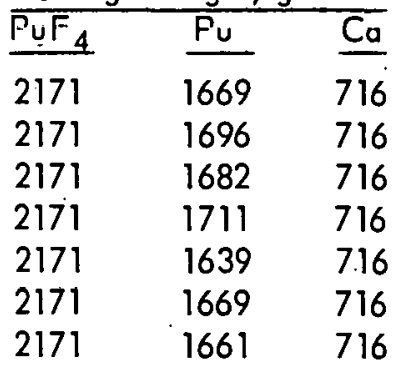

Button

\begin{tabular}{c}
$\begin{array}{c}\text { Weight, } \\
\text { grams }\end{array}$ \\
\hline 1630 \\
1572 \\
1631 \\
829 \\
1030 \\
1635 \\
1618
\end{tabular}

Yield

$\frac{\%}{97.7}$

92.7

97.0

48.5

62.8

98.0

97.4

\begin{tabular}{|c|c|}
\hline \multicolumn{2}{|c|}{ Chemical } \\
\hline$\overline{P u}$ & $F$ \\
\hline 76.9 & 20.7 \\
\hline 78.1 & 18.7 \\
\hline 77.5 & 20.8 \\
\hline 78.8 & 17.3 \\
\hline 75.5 & 22.43 \\
\hline 76.9 & 20.97 \\
\hline 76.5 & 22.11 \\
\hline
\end{tabular}

\begin{tabular}{|c|c|c|}
\hline $\mathrm{SO}_{4}$ & $\mathrm{NO}_{3}$ & $\mathrm{PuO}_{2}$ \\
\hline$<0.2$ & $<0.04$ & 8.7 \\
\hline$<0.2$ & $<0.04$ & 15. \\
\hline$<0.2$ & $<0.04$ & \\
\hline$<0.2$ & $<0.04$ & $2 v$ \\
\hline$<0.2$ & $<0.04$ & 1. \\
\hline$<0.2$ & $<0.04$ & 8. \\
\hline$<0.2$ & $<0.04$ & 4. \\
\hline
\end{tabular}


55-gallon drums, and removed from the drums in small quantities as it is needed. At the time this study was conducted, the calcium which was left in the drum was exposed to the room air until the drum was emptied, and it was possible for this calcium to react with the water in the room air and become coated with calcium hydroxide. This study was conducted to determine if the use of this partially oxidized calcium in a reduction charge would have any affect on the reduction.

The reduction charges for this study were prepared by mixing two batches of plutonium tetrafluoride together, and then splitting this double batch. One half of the double batch was used as a control charge and could be compared with the charge which used the partially oxidized calcium.

The data which were gathered during this study (Table IV) indicated that the use of partially oxidized calcium does not affect the reduction yield or the heating time, but it does affect the purity of the button. The data in Table IV show that the buttons produced with partially oxidized calcium contained from 183 to $394 \mathrm{ppm}$ more impurities than the buttons produced with the control charges.

The operating procedures have been changed since this study was conducted, and the calcium drums are now kept under an argon purge from the time the drum is opened until it is empty.

\section{LONG REDUCTION HEATING TIMES}

The reaction between plutonium tetrafluoride and calcium to form plutonium metal is initiated at Rocky Flats by inductively heating a stainless-steel pressure vessel which holds the reduction charge. Normally a heating time of about 30 to 35 minutes is required to bring the reactants up to the reaction. temperature, but quite often, about 20 to 30 percent of the time, a heating time of 45 to 60 minutes is required. In an effort to determine the cause of these long heating times, various factors such as chemical composition of the plutonium tetrafluoride, the method used to mix the charge, and many others were studied to see if any correlation existed between these factors and the long heating times. No correlation could be found for any of the above factors.

It was noticed, however, that the batches of plutonium tetrafluoride which sat for some time following fuorination before they were reduced seemed to take longer to fire than the batches which were reduced shortly after they were removed from the fluorination furnaces. An attempt was made to verify this by keeping a record of the hours in the fuorination furnace, the time difference between the end of the fluorination and the start of the reduction, and the heating time for 61 batches of the plutonium tetrafluoride. The data which were obtained from this record were analyzed by multiple regression.

It was found that the hours in the fluorination furnace did not significantly affect the heating time, but the time difference between fluorination and reduction did. The regression equation obtained by using only the time difference between fluorination and reduction is shown as follows:

$$
\begin{aligned}
& Y=31.03+0.09 X_{2} \\
& Y=\text { Heating time (minutes) } \\
& X_{2}=\text { Time difference between fluorination and }
\end{aligned}
$$

This equation shows that as the time difference between fluorination and reduction increases, the heating time increases. The equation also shows that o time difference of 11 hours between fluorination and reduction will increase the heating time by one minute. There was, however, a lot of scatter in the data and the equation is only valid in showing the general trend in the dato.

TABLE IV

DATA FOR OXIDIZED CALCIUM STUDY

Heating

Run Time, Charge Weight, grams

$$
\text { N }
$$

No. $\frac{\min .}{33}$

31.

Button

Weight, Yield Chemical Composition of $\mathrm{PuF}_{4}, \%$ grams

1292

1401

1513

1512

1514

1513

$\frac{\%}{77.6}$

78.

84.5

96.5

96.6

97.5

97.4
$\frac{\mathrm{Pu}}{78.67}$

78.29

76.81

76.69

$77.22 \quad 20.80$

$77.09 \quad 20.91$

$\frac{5}{0.34}$

$\frac{\mathrm{SO}_{4}}{0.34}$

$\mathrm{NO}$

$\mathrm{NO}_{3}$

$<0.04$

$0.39<0.04$

$0.28<0.04$

$0.27<0.04$

$<0.2<0.04$

$0.15<0.04$
$\underline{\mathrm{PuO}_{2}}$

7.2

8.8

10.2

11.8

6.9

6.7
Total

Impurities

in Button

ppm

1211

1028

927

630.

1034

844 
It is not definitely. known why the time difference between fluorination and reduction should affect the heating time. The plutonium oxide contained in the tetrafluoride is known to adsorb from 1 to 1.5 percent water by weight. This water may react with the plutonium tetrafluoride or the hydrogen fluoride adsorbed on the tetrafluoride. However, there are no firm indications that this does happen or that it would affect the heating. time even if it did happen.

\section{REDUCTION YIELD STUDY}

One of the criteria for determining the quality of the plutonium tetrafluoride produced at Rocky Flats is the metal yield which is obtained from the reduction step. The addition of iodine to the reduction charge will increase the yield. (3) It is felt, however, that the increase in yield does not justify the difficulties encountered in handling iodine and calcium iodide containing slag. Several studies have been conducted to determine the other factors which affect the reduction yield. Two of these studies, the charge mixing and oxidized calcium studies, have already been discussed. Other studies ( 1$)$ hove been made which showed that variations in the chemical composition of the plutonium tetrafluoride hove a definite affect on the reduction yield. It was felt, however, that the correlations between reduction yield and chemical composition which were obtained from these studies were of questionable value. Because of this, another. study was conducted in an attempt to obtain a better correlation.

The data for this study have been divided into two groups. The first group of data (Appendix, Table XI) was obtained at a time when the plutonium tetrafluoride contained sizable amounts of sulfate, and it is referred to as the high-sulfate data. The reduction charges for this group were prepared by mixing two batches of plutonium tetrafluoride together and then making two reductions from the mixture after it had been sampled. The second group of data (Appendix, Table XII) was obtained at a time when the sulfate content of the plutonium tetrafluoride was low, and it is referred to as the low-sulfate data. The reduction charges for this group were prepared from normal size batches which weit sumpled before they were redueed.

The data for the high-sulfate group were correlated by grouping them according to the fluoride content of the plutonium tetrafluoride. Thus, all of the batches which contained from 19.00 to 19.99 percent fluoride were

(3) Hormon, K. M., and Reas, W. J., Conversion Chemistry of Plutonium Nitrate, 1957, HW-49597-A.

(1) Conner, W. V., loc. cit., p 1. placed in one group, and the rest of the data were grouped in the same manner, as is shown in Tabl. The yields for the batches within each group , then averaged to obtain an average yield for each range of fluoride content. When the data were arranged TABLE $V$
CORRELATION OF FLUORIDE CONTENT OF PLUTONIUM TETRAFLUORIDE WITH REDUCTION YIELD FOR HIGH-SULFATE DATA

\begin{tabular}{|c|c|c|c|c|c|c|}
\hline \multirow{2}{*}{$\begin{array}{l}\text { Range } \\
\text { of } F, \% \\
\end{array}$} & \multirow{2}{*}{$\begin{array}{c}\text { Batch } \\
\text { No. }\end{array}$} & \multirow[b]{2}{*}{$\% \mathrm{~F}$} & \multirow[b]{2}{*}{$\% \mathrm{SO}_{4}$} & \multicolumn{2}{|c|}{ Yield \% } & \multirow{2}{*}{$\begin{array}{l}\text { Average } \\
\text { Yield, \% }\end{array}$} \\
\hline & & & & 1 & 2 & \\
\hline & 30 & 19.00 & 2.60 & 95.2 & 95.2 & \\
\hline & 26 & 19.40 & 3.20 & 88.8 & 91.0 & \\
\hline 19.00 & 13 & 19.51 & 4.20 & 95.6 & 96.6 & \\
\hline to & 28 & 19.61 & 4.30 & 87.0 & 86.5 & 92.7 \\
\hline \multirow[t]{3}{*}{19.99} & 9 & 19.66 & 1.38 & 94.9 & 95.0 & \\
\hline & 33 & 19.90 & 3.48 & 92.0 & 91.9 & \\
\hline & 2 & 19.96 & 1.60 & 95.4 & 93.2 & \\
\hline \multirow[t]{2}{*}{. } & 3 & 20.24 & 1.20 & 94.5 & 94.6 & \\
\hline & 12 & 20.27 & 3.54 & 87.4 & 93.3 & \\
\hline 20.00 & 14 & 20.30 & 0.90 & 94.4 & 92.6 & \\
\hline to & 40 & 20.30 & 2.70 & 94.2 & 96.2 & 93.4 \\
\hline \multirow[t]{4}{*}{20.49} & 27 & 20.36 & 1.92 & 96.5 & 96.8 & \\
\hline & 6 & 20.38 & 1.34 & 94.2 & 93.6 & \\
\hline & 1 & 20.40 & 4.13 & 91.3 & 90.6 & \\
\hline & 10 & 20.62 & 2.10 & 95.0 & 94.5 & \\
\hline 20.50 & 15 & 20.80 & 1.83 & 96.5 & 95.6 & \\
\hline to & 7 & 20.84 & 0.38 & 97.1 & 96.2 & 95.7 \\
\hline \multirow[t]{5}{*}{20.99} & 2.4 & 20.8 .5 & 1.90 & 96.3 & 97.1 & \\
\hline & 37. & 20.90 & 2.60 & 95.0 & 94.1 & \\
\hline & 20 & 21.00 & 0.66 & 94.2 & 95.1 & \\
\hline & 31 & 21.00 & 1.16 & 97.3 & 97.8 & \\
\hline & 23 & 21.10 & 0.87 & 95.9 & 95.1 & \\
\hline 21.00 & 35 & 21.20 & 0.62 & 96.1 & 96.1 & \\
\hline to & 36 & 21.20 & 1.20 & 95.2 & 95.4 & 96.1 \\
\hline \multirow[t]{7}{*}{21.49} & 21 & 21.30 & 1.94 & 95.8 & 94.7 & \\
\hline & 11 & 21.33 & 2.32 & 95.5 & 95.1 & \\
\hline & 5 & 21.34 & 1.14 & 96.3 & 97.3 & \\
\hline & 8 & 21.37 & 0.72 & 98.7 & 98.7 & \\
\hline & 17 & 21.50 & 0.82 & 96.9 & 97.8 & \\
\hline & 22 & 21.50 & 0.93 & 97.1 & 97.5 & \\
\hline & 25 & 21.52 & 1.04 & 96.8 & 95.1 & \\
\hline 21.50 & 29 & 21.52 & 1.84 & 97.6 & 96.8 & \\
\hline to & 38 & 21.55 & 1.16 & 97.8 & 97.3 & 97.1 \\
\hline \multirow[t]{4}{*}{21.99} & 19 & 21.70 & 1.10 & 98.2 & 97.9 & \\
\hline & 34 & 21.70 & 1.56 & 97.1 & 96.4 & \\
\hline & 39 & 21.80 & 1.05 & 91.9 & 96.4 & \\
\hline & 16 & 21.90 & 0.76 & 97.0 & 97.1 & \\
\hline 22.00 & 4 & 22.16 & 0.88 & 95.4 & 97.1 & \\
\hline to & 18 & 22.20 & 1.43 & 97.1 & 97.3 & 97.3 \\
\hline 22.99 & 32 & 22.30 & 0.75 & 99.3 & 97.8 & \\
\hline
\end{tabular}


in this manner, it was found that the overage yield increased os the fluoride content of the plutonium tetrafluoride increased.

The data for the low-sulfate group were correlated in the same manner as the data for the high-sulfate group. The data for this group (Table VI) also show that the overage yield increased as the fluoride content of the plutonium tetrafluoride increased. It was found, however, that the overage yield for a given range of fluoride content was higher for the low-sulfate data than it was for the high-sulfate data. This agrees with the results of other studies which have shown that sulfate in the plutonium tetrafluoride has a detrimental effect on the reduction yield.

\section{TABLE VI}

CORRELATION OF FLUORIDE CONTENT OF PLLUTONIUM TETRAFLUORIDE WITH REDUCTION YIELD FOR LOW.SULFATE DATA

\begin{tabular}{|c|c|c|c|c|c|}
\hline $\begin{array}{l}\text { Range } \\
\text { of } F, \%\end{array}$ & $\begin{array}{c}\text { Batch } \\
\text { No. }\end{array}$ & $\% \mathrm{~F}$ & $\% \mathrm{SO}_{4}$ & $\begin{array}{c}\text { Yield } \\
\%\end{array}$ & $\begin{array}{l}\text { Average } \\
\text { Yield, \% }\end{array}$ \\
\hline & 25 & 17.05 & 0.32 & 77.6 & \\
\hline 17.00 & 10 & 17.25 & $<0.20$ & 86.4 & \\
\hline to & 9 & 17.32 & 0.20 & $89: 7$ & 83.2 \\
\hline \multirow[t]{3}{*}{17.99} & 26 & 17.34 & 0.37 & 84.6 & \\
\hline & 40 & 17.90 & 0.75 & 77.7 & \\
\hline & 7 & 18.20 & $<0.20$ & 90.8 & \\
\hline 18.00 & 49 & 18.70 & $<0.20$ & 92.7 & \\
\hline to & 16 & 18.70 & 0.35 & 93.2 & 91.1 \\
\hline \multirow{7}{*}{18.99} & 43 & 18.80 & $<0.20$ & 83.5 & \\
\hline & 6 & 18.85 & $<0.20$ & 93.4 & \\
\hline & 41 & 18.90 & $<0.20$ & 92.7 & \\
\hline & 17 & 19.00 & 0.55 & 97.3 & \\
\hline & 42 & 19.00 & 0.58 & 93.9 & \\
\hline & 47 & 19.00 & $<0.20$ & 95.1 & \\
\hline & 2 & 19.04 & 0.68 & 93.8 & \\
\hline 19.00 & 1 & 19.16 & $<0.20$ & 95.7 & \\
\hline to & 46 & 19.30 & 0.36 & 97.2 & 95.0 \\
\hline \multirow[t]{7}{*}{19.99} & 31 & 19.33 & 0.24 & 95.5 & \\
\hline & 8 & 19.40 & 0.20 & 92.0 & \\
\hline & 24 & 19.70 & $<0.20$ & 96.7 & \\
\hline & 45 & 19.84 & $<0.20$ & 96.7 & \\
\hline & 32 & 19.99 & 0.36 & 96.5 & \\
\hline & 27 & 20.00 & 0.36 & 96.5 & \\
\hline & 11 & 20.08 & 0.37 & 97.1 & \\
\hline 20.00 & 28 & 20.17 & 0.38 & 96.6 & \\
\hline to & 22 & 20.20 & 0.36 & 96.9 & 96.9 \\
\hline \multirow[t]{3}{*}{20.49} & 37 & 20.21 & 0.48 & 95.7 & \\
\hline & 38 & 20.23 & $<0.20$ & 97.6 & \\
\hline & 23 & 20.30 & $<0.20$ & 97.1 & \\
\hline
\end{tabular}

TABLE VI (Concluded)

CORRELATION OF FLUORIDE CONTENT OF PLUTONIUM TETRAFLUORIDE WITH REDUCTION YIELD FOR LOW-SULFATE DATA

\begin{tabular}{|c|c|c|c|c|c|}
\hline $\begin{array}{l}\text { Range } \\
\text { of } F, \% \\
\end{array}$ & $\begin{array}{c}\text { Batch } \\
\text { No. }\end{array}$ & $\% \mathrm{~F}$ & $\% \mathrm{SO}_{4}$ & $\begin{array}{c}\text { Yield } \\
\% \\
\end{array}$ & $\begin{array}{l}\text { Average } \\
\text { Yield, \% } \\
\end{array}$ \\
\hline 20.00 & 21 & 20.40 & $<0.20$ & 96.3 & \\
\hline to & 36 & 20.40 & 0.25 & 96.9 & 96.9 \\
\hline 20.49 & 35 & 20.44 & 0.36 & .97 .2 & \\
\hline \multirow[t]{4}{*}{ Cont } & 30 & 20.47 & $<0.20$ & 97.5 & \\
\hline & 18 & 20.62 & 0.50 & 96.0 & \\
\hline & 48 & 20.70 & $<0.20$ & 97.7 & \\
\hline & 33 & 20.70 & 0.68 & 96.7 & \\
\hline 20.50 & 34 & 20.71 & $<0.20$ & 97.7 & \\
\hline to & 12 & 20.74 & 0.88 & 97.7 & 97.3 \\
\hline \multirow[t]{5}{*}{20.99} & 39 & 20.78 & $<0.20$ & 97.4 & \\
\hline & 50 & 20.80 & $<0.20$ & 97.0 & \\
\hline & 29 & 20.95 & $<0.20$ & 97.4 & \\
\hline & 51 & 20.97 & $<0.20$ & 98.0 & \\
\hline & 44 & 21.10 & 0.46 & 96.1 & \\
\hline 21.00 & 4 & 21.30 & $<0.20$ & 97.7 & \\
\hline to & 5 & 21.40 & $<0.20$ & 97.9 & 97.1 \\
\hline \multirow[t]{3}{*}{21.99} & 20 & 21.90 & $<0.20$ & 96.3 & \\
\hline & 3 & 21.92 & 0.51 & 97.5 & \\
\hline & 15 & 22.00 & $<0.20$ & 95.6 & \\
\hline 22.00 & 52 & 22.11 & $<0.20$ & 97.4 & \\
\hline to & 19 & 22.30 & 0.20 & 98.1 & 98.2 \\
\hline \multirow[t]{2}{*}{22.99} & 14 & 22.80 & 0.25 & 100 & \\
\hline & 13 & 22.87 & 0.34 & 100 & \\
\hline
\end{tabular}

The data for the low-sulfate group were also correlated by grouping them according to the plutonium content of the plutonium tetrafluoride. This method of arranging the data (Table VII) showed that the reduction yield decreased as the plutonium content of the plutonium tetrafluoride increased. This result was expected since the plutonium content of plutonium tetrafluoride decreases as the fluoride content increases, due to the decrease in the amount of plutonium oxide contained in the tetrafluoride.

The results of this study are summarized in Table VIII and Figure 2. Table VIII contains one item that has not previously been mentioned. The ranges of reduction yield which are shown in Toble VIII are quite wide and they give an indication of the amount of scatter in the dato. It can be said, though, that on the average, the reduction yield will increase as the fluoride content of the plutonium tetrafluoride increases and the yield will decrease as the plutonium content 
TABLE VII

CORRELATION OF PLUTONIUM CONTENT OF PLUTONIUM TETRAFLUORIDE WITH REDUCTION YIELD FOR LOW-SULFATE DATA

\begin{tabular}{|c|c|c|c|c|c|}
\hline $\begin{array}{c}\text { Range } \\
\text { of } P_{u}, \%\end{array}$ & $\begin{array}{c}\text { Batch } \\
\text { No. }\end{array}$ & $\% \mathrm{Pu}$ & $\% \mathrm{~F}$ & $\begin{array}{c}\text { Yield } \\
\% \\
\end{array}$ & $\begin{array}{l}\text { Average } \\
\text { Yield, \% }\end{array}$ \\
\hline 75.50 & 14 & 75.92 & 22.80 & 100 & \\
\hline to & 13 & 75.9 .3 & 22.87 & 100 & 98.5 \\
\hline \multirow[t]{5}{*}{76.49} & 15 & .76 .15 & 22.00 & 95.6 & \\
\hline & 52 & 76.50 & 22.11 & 97.4 & \\
\hline & 19 & 76.52 & 22.30 & 98.1 & \\
\hline & 5 & 76.56 & 21.40 & 97.9 & \\
\hline & 3 & 76.51 & 21.92 & 37.5- & \\
\hline 76.50 & 28 & 76.71 & 20.17 & 96.6 & \\
\hline to & 33 & 76.73 & 20.70 & 96.5 & 97.3 \\
\hline \multirow[t]{8}{*}{76.99} & 20 & $\overline{76.75}$ & 21.90 & 96.3 & \\
\hline & 27 & 76.86 & 20.00 & 96.5 & \\
\hline & 48 & 76.90 & 20.70 & 97.7 & \\
\hline & 51 & 76.90 & 20.97 & 98.0 & \\
\hline & 12 & 76.96 & 20.74 & 97.7 & \\
\hline & 36 & 76.98 & 20.40 & 96.9 & \\
\hline & 4 & 77.00 & 21.30 & 97.7 & \\
\hline & 35 & 77.07 & 20.44 & 97.2 & \\
\hline & 39 & 77.09 & 20.78 & 97.4 & \\
\hline & 29 & 77.09 & 20.95 & 97.4 & \\
\hline 77.00 & 34 & 77.12 & 20.71 & 97.7 & \\
\hline to & 30 & 77.15 & 20.47 & 97.5 & 96.4 \\
\hline \multirow[t]{5}{*}{77,49} & 22 & 77.15 & 20.20 & 96.9 & \\
\hline & 23 & 77.19 & 20.30 & 97.1 & \\
\hline & 38 & 77.28 & $20: 23$ & 97.6 & \\
\hline & 37 & 77.35 & 20.21 & 95.7 & \\
\hline & 44 & 77.35 & 21.10 & 96.1 & \\
\hline
\end{tabular}

TABLE VII (Concluded)

. CORRELATION OF PLUTONIUM CONTENT OF PLUTONIUM TETRAFLUORIDE WITH REDUCTION YIELD FOR LOW-SULFATE DATA

\begin{tabular}{|c|c|c|c|c|c|}
\hline $\begin{array}{c}\text { Range } \\
\text { of } P_{U}, \%\end{array}$ & $\begin{array}{c}\text { Batch } \\
\text { No. }\end{array}$ & $\% \mathrm{Pu}$ & $\% \mathrm{~F}$ & $\begin{array}{c}\text { Yield } \\
\% \\
\end{array}$ & $\begin{array}{l}\text { Average } \\
\text { Yield, \% } \\
\end{array}$ \\
\hline 77.00 & 21 & 77.37 & 20.40 & 96.3 & \\
\hline to & 24 & 77.44 & 19.70 & 96.7 & 96.4 \\
\hline 77.49 & 45 & 77.46 & 19.84 & 90.7 & \\
\hline \multirow[t]{4}{*}{ Cont } & 42 & 77.49 & 19.00 & $93: 9$ & \\
\hline & 11 & 77.50 & 20.08 & 97.1 & \\
\hline & 50 & 77.50 & $20: 80$ & $97: 0$ & \\
\hline & 18 & $7 \% .5 \%$ & $2 \|, 6)$ & $\ddot{x}$ & \\
\hline 77.50 & 46 & 77.55 & 19.30 & 97.2 & \\
\hline to & 40 & 77.58 & 17.90 & 77.7 & 93.9 \\
\hline \multirow[t]{7}{*}{77.99} & 32 & 77.60 & 19.99 & 96.5 & \\
\hline & 31 & 77.62 & 19.33 & 95.5 & \\
\hline & 16 & 77.80 & 18.70 & 93.2 & \\
\hline & 47 & 77.80 & 19.00 & 95.1 & \\
\hline & 2 & 77.84 & 19.04 & 93.8 & \\
\hline & 43 & 78.00 & 18.80 & 83.5 & \\
\hline & 17 & 78.00 & 19.00 & 97.3 & \\
\hline 78.00 & 49 & 78.10 & 18.7 & 92.7 & \\
\hline to & 41 & 78.15 & 18.90 & 92.7 & 91.8 \\
\hline \multirow[t]{4}{*}{78.49} & 8 & 78.15 & 19.40 & 92.0 & \\
\hline & 9 & 78.34 & 17.32 & 89.7 & \\
\hline & 7 & 78.40 & 18.20 & 90.8 & \\
\hline & 1 & 78.41 & 19.16 & $.95: 7$ & \\
\hline 78.50 & 6 & 78.56 & $18: 83$ & 93.4 & \\
\hline to & 26 & 79.15 & 17.34 & 84.6 & 85.5 \\
\hline \multirow[t]{2}{*}{79.50} & 10 & 79.35 & 17.25 & 86.4 & \\
\hline & 25 & 7.9 .50 & 17.05 & 77.6 & \\
\hline
\end{tabular}

TABLE VIII

SUMMARY OF INFORMATION FROM REDUCTION YIELD STUDY

Correlation Between Percent Fluoride and Reduction Yield High-Sulfate Data
Low-Sulfate Data

Range
of

Range Number Average Yield

of $F, \%$ of ltems Yield, \% \%

19.00

to
19.99

20.00

to

20.49
14

14

$14-93.4$

\begin{abstract}
92.7
\end{abstract}

$$
87.0
$$

to

96.6

87.4

to

96.8

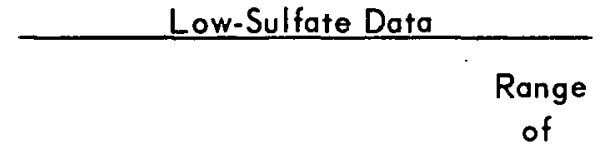

Range Number Average Yield of $F, \%$.

$$
17.00
$$

to

17.99

18.00

to 18.99

89.7

83.5

6

91.1
Correlation Between Percent Plutonium and Reduction Yield for Low-Sulfate Data

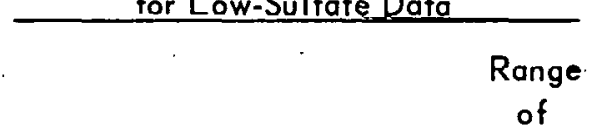

Range Number Average Yield of F, \% of Items Yield, \% \%

75.50

to
76.49

76.50
3

95.6

ic.

96.3

$12 \quad 97.3$

98.1 to

76.99 to
93.4 
TABLE VIII (Concluded)

SUMMARY OF INFORMATION FROM REDUCTION YIELD STUDY

Correlation Between Percent Fluoride and Reduction Yield

High-Sulfate Data

\begin{tabular}{c}
\hline \\
Range \\
of $F, \%$ \\
\hline 20.50 \\
to \\
20.99 \\
21.00 \\
to \\
21.45 \\
21.50 \\
to \\
21.99 \\
22.00
\end{tabular}

to

22.99

Low-Sulfate Data

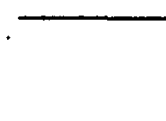

Number Average Yield

of Items

Yield, \% $\frac{\%}{94.1}$

10

18

18

6
Range

of

95.7

to

97.1

94.2

96.1

to

98.7

95.1

97.1

to

98.2

95.4

\section{Low-Sulfate Data}

$\frac{\begin{array}{c}\text { Range } \\ \text { of F,\% }\end{array}}{19.00} \frac{\begin{array}{c}\text { Number } \\ \text { of Items }\end{array}}{\therefore} \frac{\begin{array}{c}\text { Average } \\ \text { Yield, \% }\end{array}}{\frac{\begin{array}{c}\text { Yield } \\ \%\end{array}}{90.7}}$

, to 11

19.99

20.00

to

20.49

20.50

to

20.99

21.00

97.3 to

99.3
11

9

Range

of

to

97.3

95.7

96.9

to

97.6

96.0

97.3

to

98.0

96.1

5

97.1

to

97.9

95.6

5

98.2

\begin{abstract}
to
\end{abstract}
21.99

22.00

to

22.99
Correlation Between Percent

Plutonium and Reduction Yield for Low-Sulfate Data

\begin{tabular}{|c|c|c|c|}
\hline $\begin{array}{l}\text { Range } \\
\text { of } F, \% \\
\end{array}$ & $\begin{array}{l}\text { Number } \\
\text { of Items }\end{array}$ & $\begin{array}{l}\text { Average } \\
\text { Yield, \% }\end{array}$ & $\begin{array}{c}\text { Range } \\
\text { of } \\
\text { Yield } \\
\% \\
\end{array}$ \\
\hline $\begin{array}{c}77.00 \\
\text { to } \\
77.49\end{array}$ & 15 & 96.4 & $\begin{array}{c}90.7 \\
\text { to } \\
97.7\end{array}$ \\
\hline $\begin{array}{c}77.50 \\
\text { to } \\
77.99\end{array}$ & 10 & 93.9 & $\begin{array}{c}77.7 \\
\text { to } \\
97.2\end{array}$ \\
\hline $\begin{array}{c}78.00 \\
\text { to } \\
78.49\end{array}$ & 8 & 91.8 & $\begin{array}{c}83.5 \\
\text { to } \\
97.3\end{array}$ \\
\hline $\begin{array}{c}78.50 \\
\text { to }\end{array}$ & 4 & 85.5 & $\begin{array}{c}77.6 \\
\text { to }\end{array}$ \\
\hline 79.50 & & & 93.4 \\
\hline
\end{tabular}

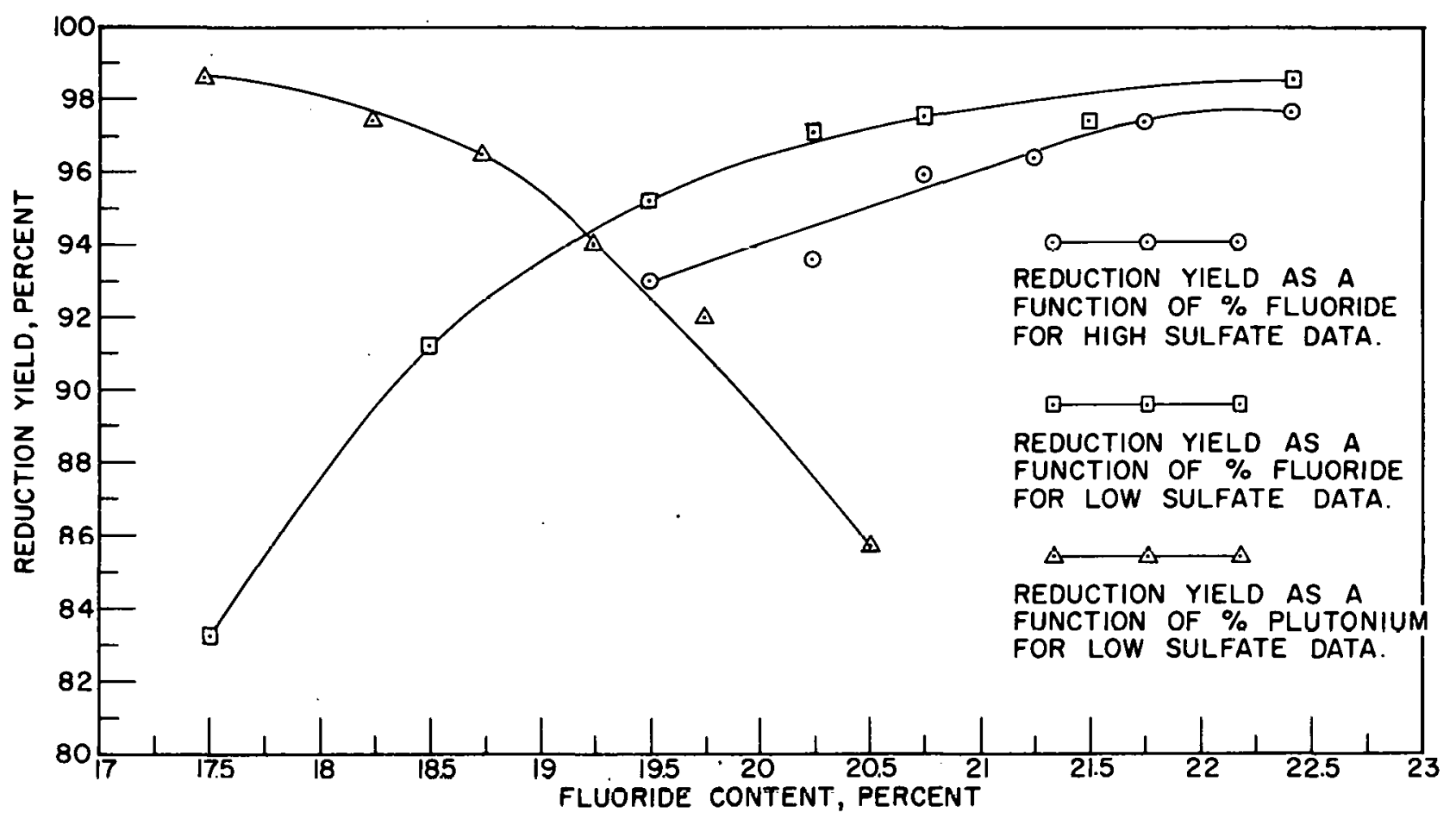

$\begin{array}{llllllllll}75.5 & 76 & 76.5 & 77 & 77.5 & 78 & 78.5 & 79 & 79.5 & 80\end{array}$ PLUTONIUM CONTENT, PERCENT

Figure 2. SUMMARY OF RESULTS OF REDUCTION YIELD STUDY 
of the plutonium tetrafluoride increases. Also, previous studies( 1 ) have been.made which show that the yield is adversely affected if the tetrafluoride contains over 1 or 2 percent sulfate, and this study would tend to confirm these results.

\section{REDUCTION SLAG STUDY}

The reaction between calcium and plutonium tetrafluoride produces a metal button and a slag which forms above the button. The slag is primarily calcium fluoride, but it contains some calcium oxide. While conducting the studies on the reduction process which has been described above, it was noticed that occassionally pieces of plutonium metal are trapped in the slags from low yield reductions. Because of this a

(1) Conner, W. V., loc. cit., p 1. study was started to inspect the slags from all reductions with yields of 94 percent -or less for trappe pieces of plutonium metal.

\section{Recovery of Plutonium Metal from Reduction Slag}

During the course of this study 22 slags from low yield reductions were inspected (Table $\mid X$ ) and a total of 2219 grams of plutonium metal were recovered from these slags. For the period covered by this study, metal was recovered from about one out of every 18 reduction slags. It was observed that the recoverable pieces of plutonium metal occurred in one or all of the following. locations:

In the sand around the bottom of the cracked crucibles.

TABLE IX

DATA ON METAL RECOVERED FROM REDUCTION SLAGS

\begin{tabular}{|c|c|c|c|c|c|c|}
\hline Slag No. & $\begin{array}{c}\text { Weight Pu Charged, } \\
\text { yrumis }\end{array}$ & & $\begin{array}{c}\text { Button Weight,. } \\
\text { grams }\end{array}$ & $\begin{array}{c}\text { Reported Yield* } \\
\% \\
\end{array}$ & $\begin{array}{c}\text { Weight of } \mathrm{Pu} \\
\text { Recovered From Slag, } \\
\text { groms } \\
\end{array}$ & $\begin{array}{l}\text { Weight of Pu } \\
\text { Left in Slag, } \\
\text { grams }\end{array}$ \\
\hline 1 & 1650 & & 1326 & 80.4 & 147 & 177 \\
\hline 2 & .1526 & & 1378 & 90.3 & 121 & 27 \\
\hline 3 & 1589 & & 1434 & 90.2 & 111 & 44. \\
\hline 4 & 1612 & & 1549 & 96.1 & 27 & 36 \\
\hline 5 & 1286 & & 891 & 6.9 .3 & - & 395 \\
\hline 6 & 1519 & & 1278 & 84.1 & - & 241 \\
\hline 7 & 1623 & & 1506 & 92.8 & 25 & 92 \\
\hline 8 & 1650 & . & 1412 & 85.6 & - & 238 \\
\hline 9 & 1622 & .. & 1499 & 92.4 & 12 & וודו \\
\hline 10 & 1607 & & 1253 & 78.0 & 312 & 42 \\
\hline 11 & 1618 & & 1487 & 91.9 & 107 & 24 \\
\hline 12 & 1517 & & 1436 & 94.7 & - & 81 \\
\hline 13 & 1530 & & 1424 & 93.1 & - & 106 \\
\hline 14 & $: 1650$ & & 1399 & 84.8 & 202 & 49 \\
\hline 15 & 1650 & & 1467 & 88.9 & 161 & 22 \\
\hline 16 & 1850 & & 1370 & 74.1 & 285 & 195 \\
\hline 17 & 1650 & & 1529 & 92.7 & 113 & 8 \\
\hline 18 & 1650 & & 1478 & 89.6 & 79 & 93 \\
\hline 19 & 1650 & & 1482 & 89.8 & 139 & 29 \\
\hline 20 & 1650 & & 1430 & 86.7 & 190 & 30 \\
\hline 21 & 1650 & & 1475 & 89.4 & 128 & 47 \\
\hline 22 & 1650 & & 1436 & 87.0 & 160 & 54 \\
\hline 23 & 1650 & & $1439^{\circ}$ & . $\quad 87.0$ & - & 211 \\
\hline 24 & 1650 & . & -1610 & 97.6 & - & 40 \\
\hline
\end{tabular}


- Between the button and the bottom of the crucible.

- In the bottom one-fourth of the slag, usually very close to the bottom of the slag.

- In a thin ring between the slag and the crucible.

In an effort to better determine the Incation of the plutonium metal, which was Irupped in Iliese slugs, rudiugraphs were taken of several slags from low yield reductions. The prints of the rudiographs ${ }^{*}$ whlch were raken of slaq No. 14 are shown in Figures 3 and 4. This reduction produced a metal yield of 84.8 percent, with 251 grams of metal being left in the slag. Most of this metal was trapped in the bottom portion of the slag, but a thin strip of metal was trapped between the slaq and the crucible wall. Photographs were also taken of this slag and they are shown in Figures 5 and 6 . Figure 5 shows the bottom of the slag and a large regular piece of trapped metal and Figure 6 shows the metal after it was removed from the slag.

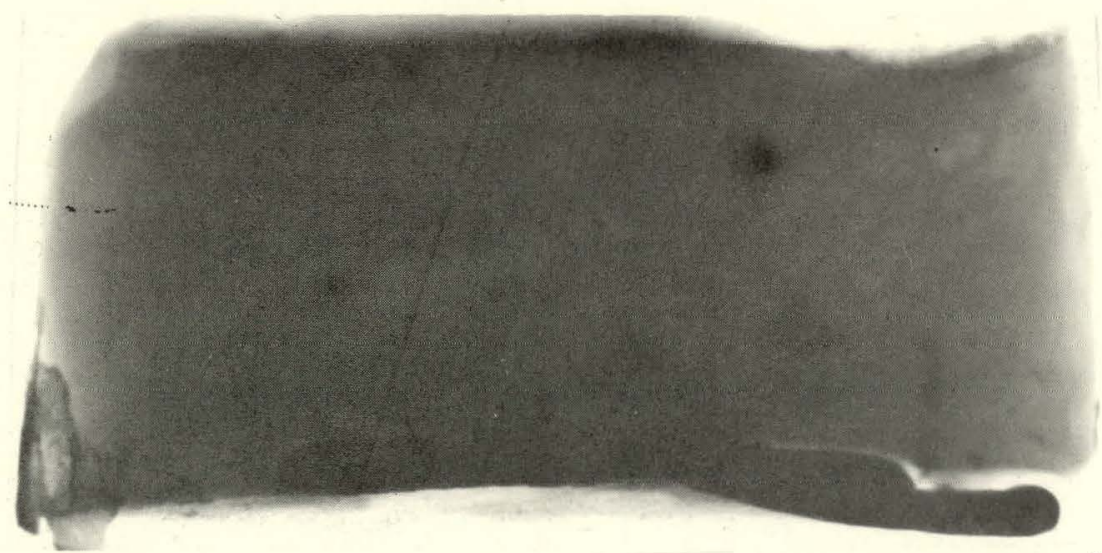

Figure 4. SIDE VIEW OF SLAG No. 14

Radiographs were also taken of slags No. 17 and 23. The reduction for slag No. 17 produced a metal yield of 92.7 percent, with 113 grams of metal being left in the slag. The majority of the metal which did not form in the button was trapped between the crucible wall and the slag (Figures 7 and 8 ) and the rest of the metal was trapped in the bottom of the slag in the form of small beads.

\footnotetext{
* The plutonium metal is the darkest portion of the print.
}

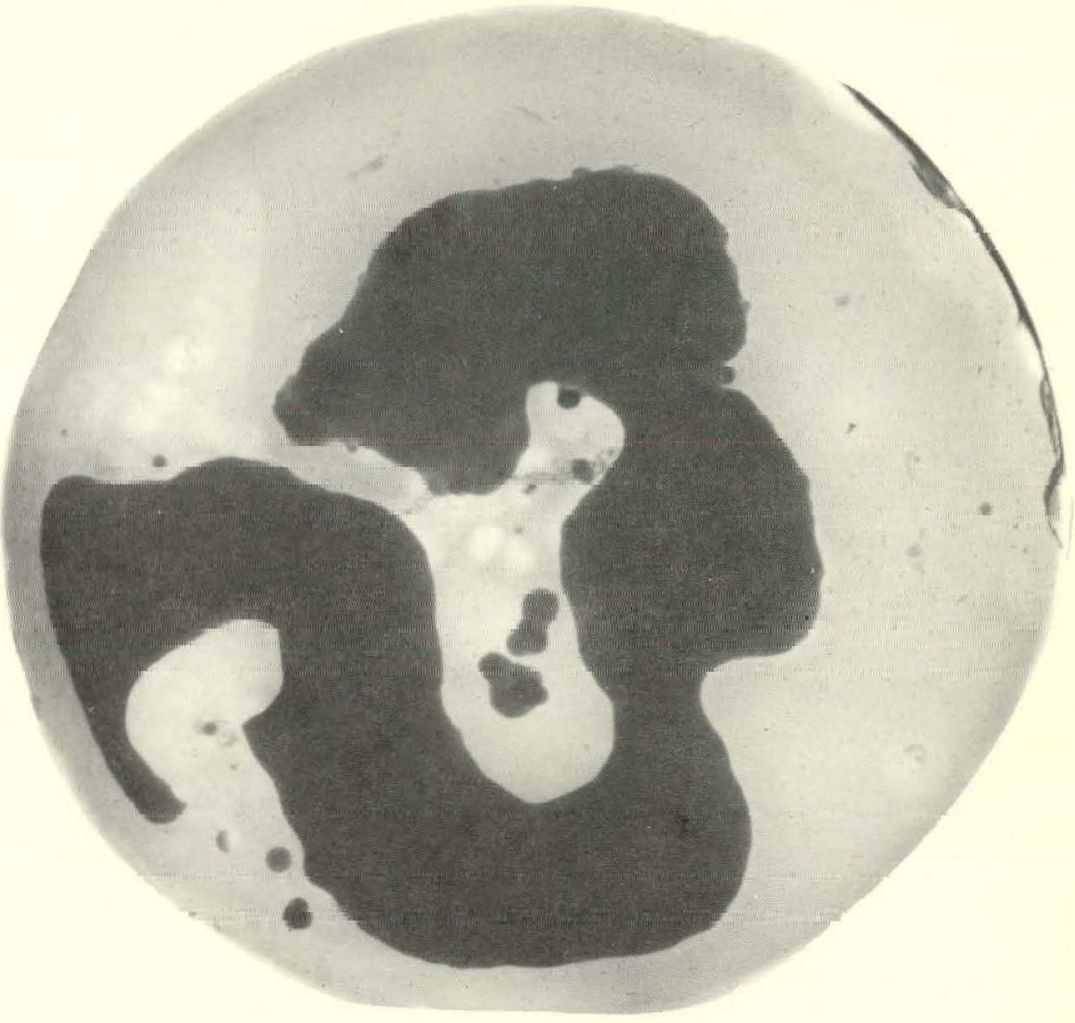

Figure 3. TOP VIEW OF SLAG No. 14 showing trapped plutonium metal

A metal yield of 87.2 percent was produced by the reduction for slag No. 23, and 211 grams of metal were left in the slag. In spite of the fact that this slag contained a large amount of metal, no large pieces of metal were found in the slag. A good portion of this slag was frozen to the walls of the crucible and the rest of the slag was poorly formed. The prints of the radiographs which were taken of this slag (Figures 9 and 10) show that the reason no large pieces of metal were found in this slag was that the metal was distributed throughout the slag in fairly small pieces. This slag had apparently frozen before the metal could collect into pieces large enough to recover.

Several other slags (Table IX) which were inspected did not contain any pieces of metal which were large enough to recover; the metal being in the form of small pieces or beads. When it was found that these slags, and slags No. 17 and 23, contained small beads of plutonium metal, it was decided that radiographs should also be taken of slags from high yield reduction. One of these reductions, for slag No. 24, produced a metal yield of 97.6 percent, with 40 grams of metal remaining 


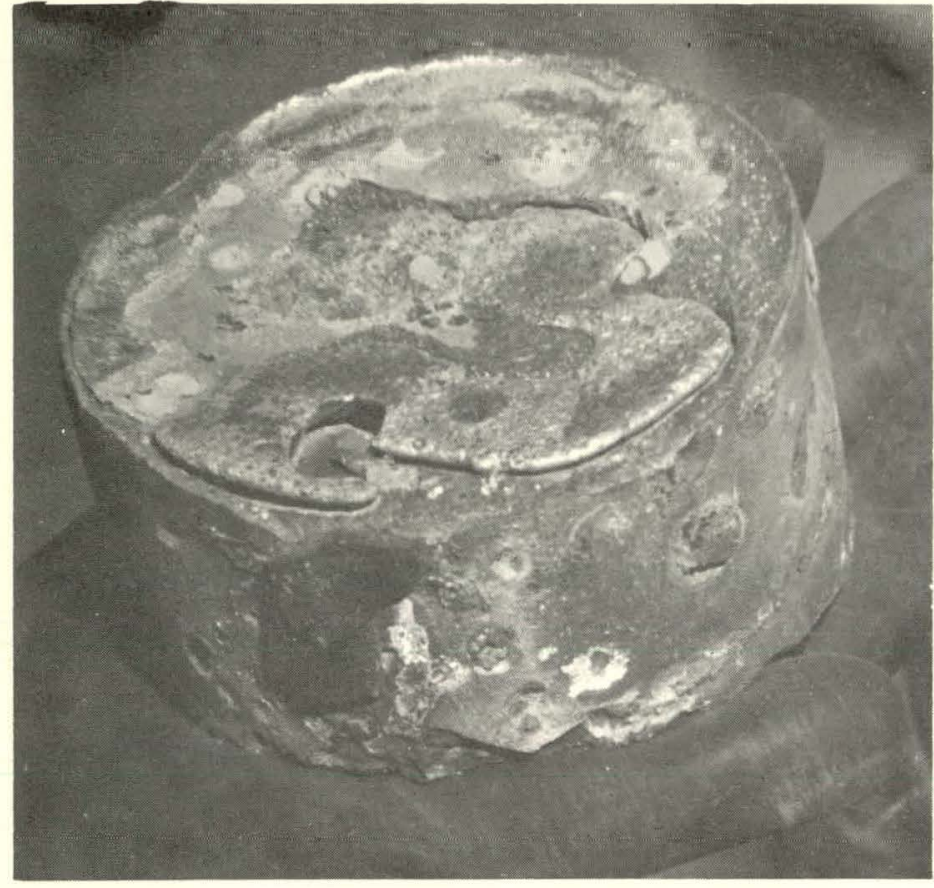

$9350-9$

Figure 5. BOTTOM OF SLAG No. 14 and piece of trapped plutonium metal

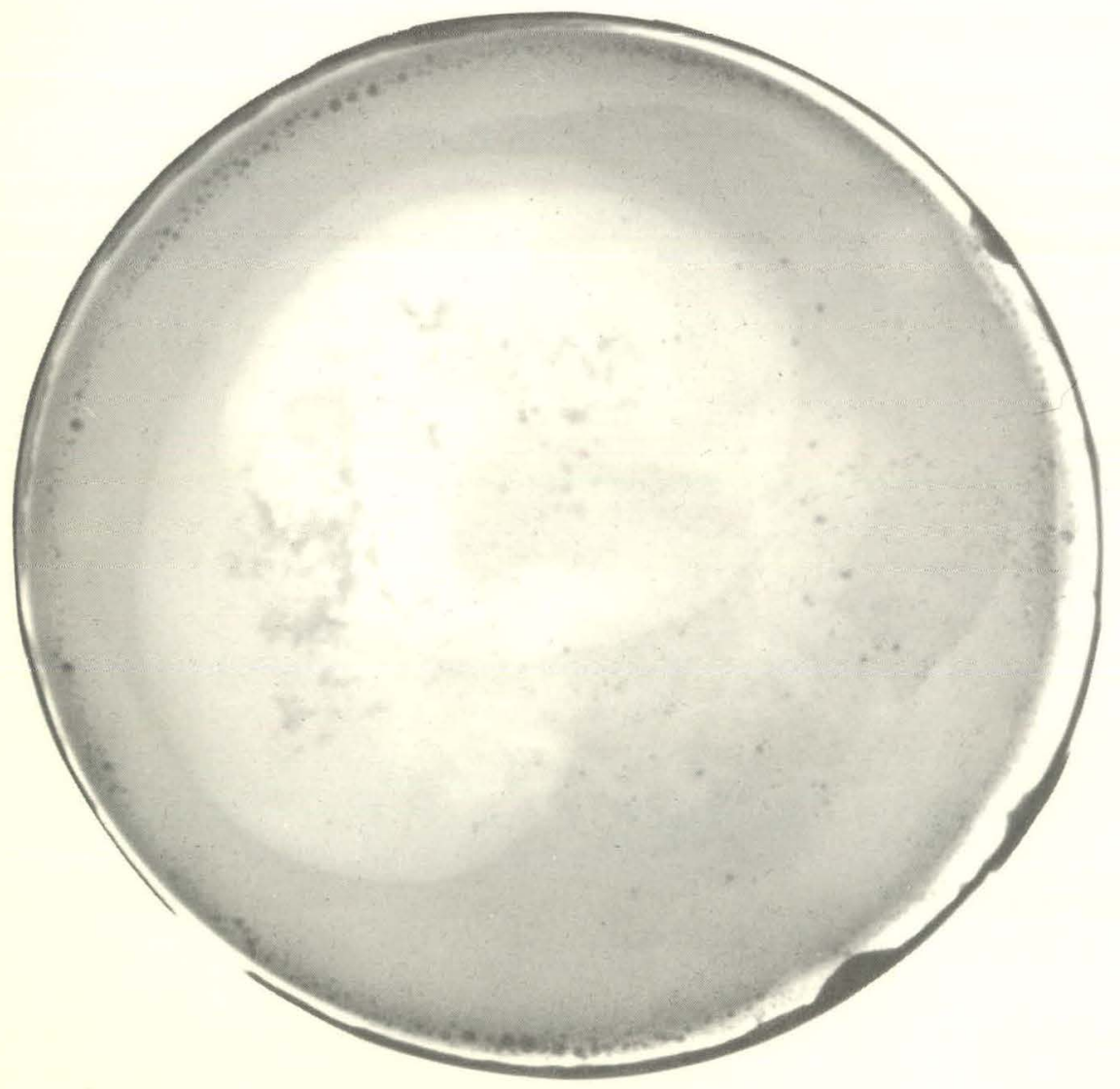

Figure 7. TOP VIEW OF SLAG No. 17 showing ring of plutonium metal trapped between slag and crucible wall, and small beads of plutonium metal trapped in bottom of slag

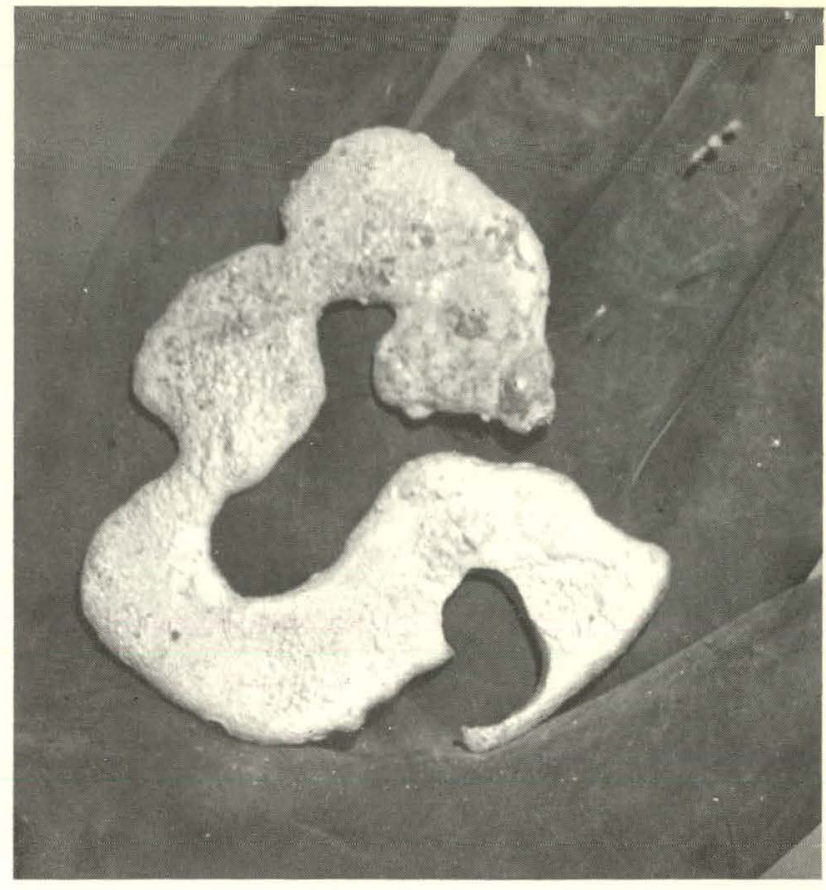

$9350-1$

Figure 6. PIECE OF PLUTONIUM METAL removed from slag No. 14

in the slag. When the radiographs of this slag were inspected (Figures 11, 12 , and 13) it was found that small beads of plutonium metal were trapped in the lower portion of the slag. The radiographs of the slags from the other high yield reductions also showed small beads of metal trapped in the lower portion of the slag. Laboratory analysis of the beads from several of these slags confirmed that the beads were plutonium metal.

In view of this information it would appear that the reduction reaction is close to 100 percent efficient, but the collection of the metal into a button is not. It is very possible that most of the plutonium left in the slags from normal reductions is in the form of small metal beads. It is felt, therefore, that it should be possible to recover these small beads of plutonium metal by some method other than the wet chemical methods normally used to process reduction slags.

The production procedures have nc been changed so that all slags from low yield reductions are broken and inspected for large pieces of plutonium metal. 
Figure 8. SIDE VIEW OF SLAG No. 17

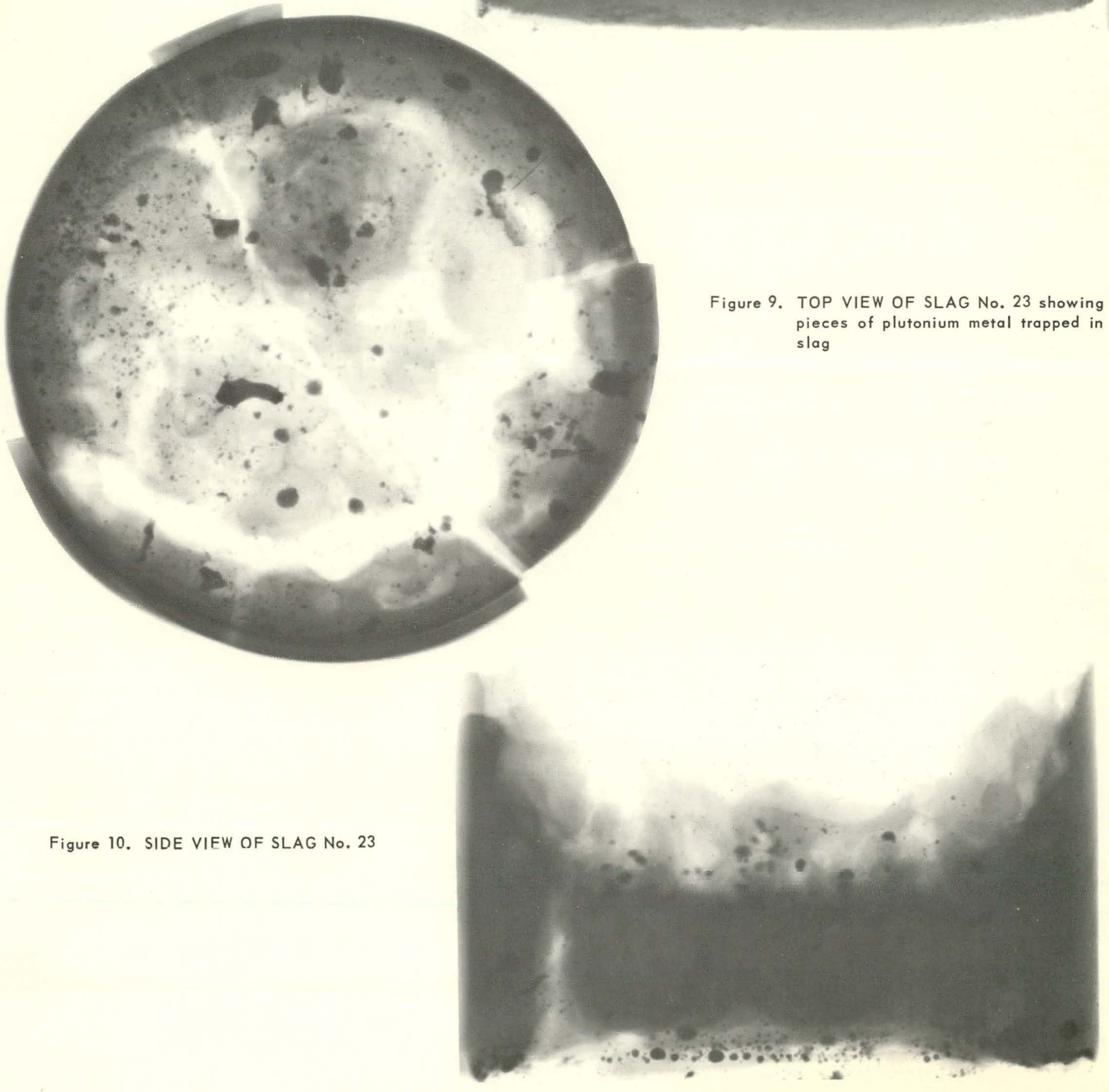


Figure 11. TOP VIEW OF SLAG No. 24 showing small beads of plutonium metal trapped in bottom of slag
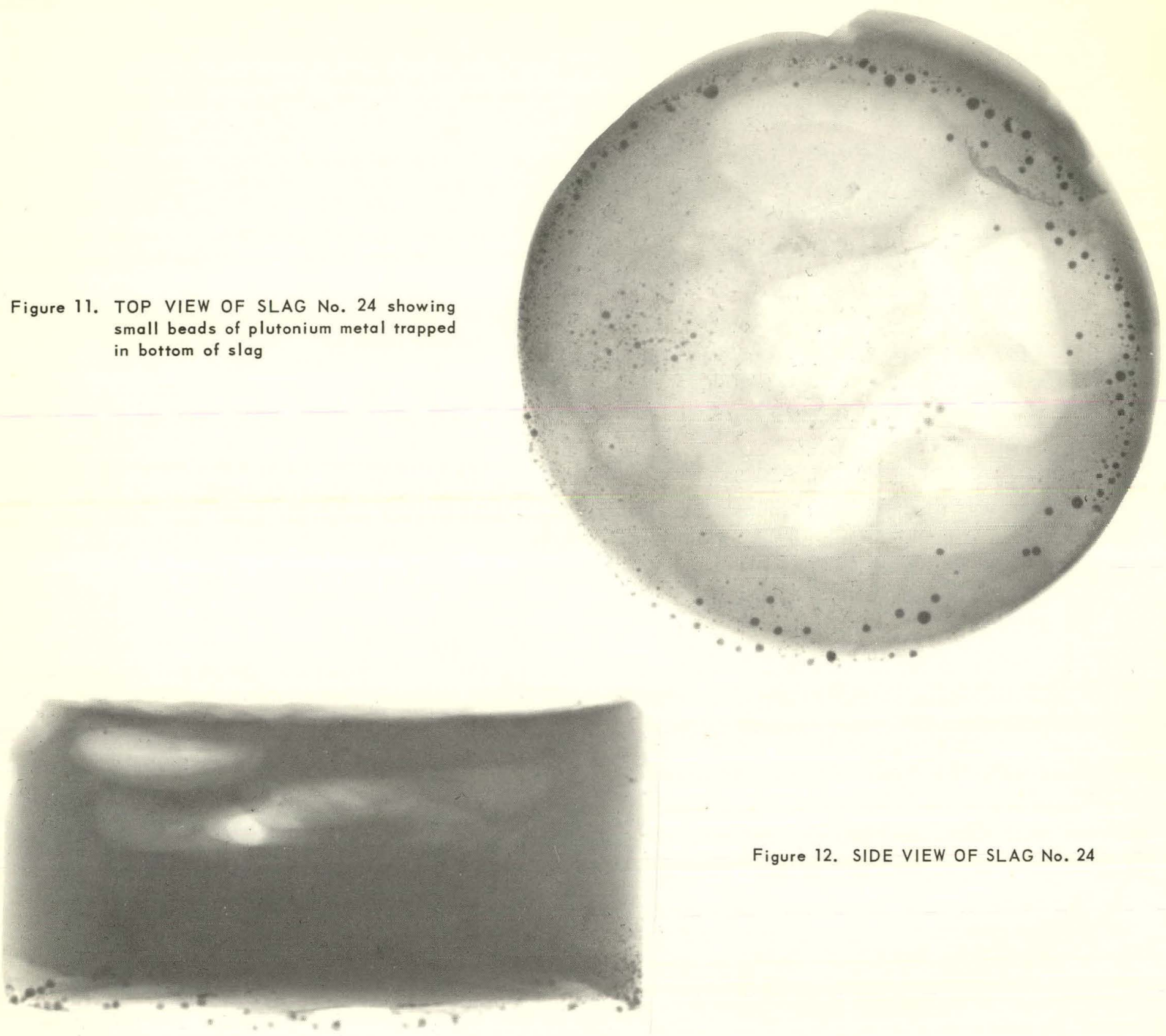

Figure 12. SIDE VIEW OF SLAG No. 24

Figure 13. SIDE VIEW OF SLAG No. 24 turned 90 degrees from position in Figure 12

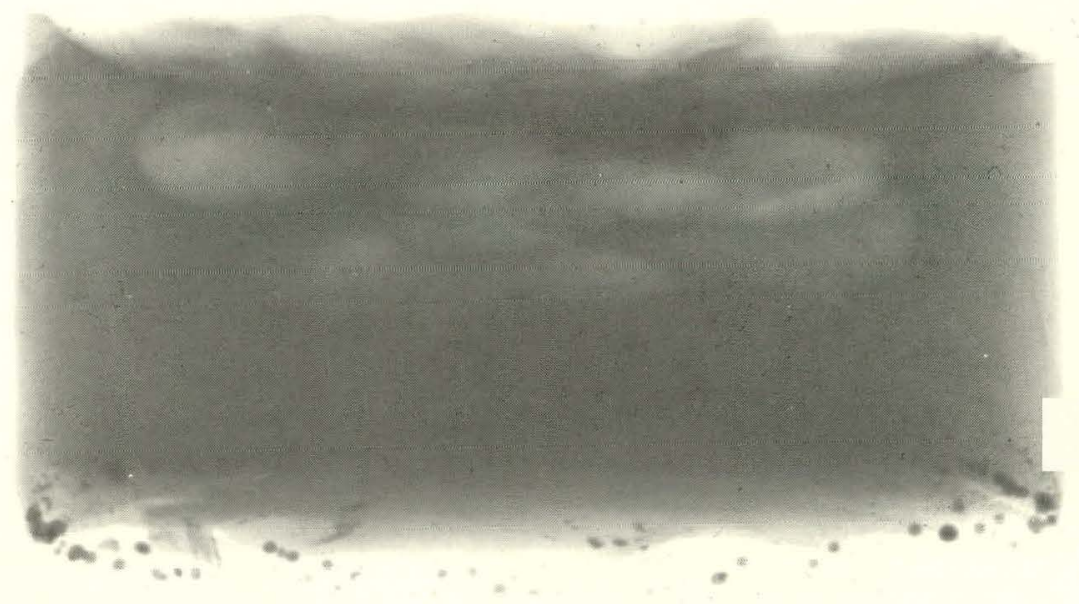


Processing of Recovered Plutonium Metal

As the study progressed and it was determined that plutonium metal could be recovered from low yield reduction slags, another study was initiated to determine the best method for processing this recovered metal. It would, of course, be possible to convert this metal to plutonium oxide and then process it in the normal manner, but it was felt that it might be possible to add the recovered metal to a normal reduction charge and save most of the normal processing costs. The success of this method would, of course, depend upon whether the addition of the recovered metal to a reduction charge would have any affect on the reduction yield or button purity. The recovered metal which was added to the reduction charges which were prepared for this study was in the same condition as it had been when it was recovered from the slag. No attempt was made to clean the metal before it was added to the charge. Approximately 200 grams of metal were added to each charge and it was placed at various locations in the charges to see if the location of the metal would have any effect on the reduction yield or button purity.

It was found that the addition of recovered metal to a reduction charge did not adversely affect either the reduction yield or metal purity. The yields given in Table $X$ show that there is sufficient heat generated by the reduction to melt the extra metal and to keep the slag molten long enought to allow this metal and the metal generated by the reduction to collect into a button. It was found, however, that the location of the recovered metal in the charge did have an effect on the formation of the button. The metal added to the charge for run No. 3 was placed on the bottom of the crucible and the button produced by this reduction was rough and poorly formed. The runs which were made by placing the recovered metal either in or on top of the charge produced fairly smooth, well formed buttons.

Run No. 1 was made without the addition of any recovered metal. A comporison of the impurities in the button produced by this control-run with the impurities in the other buttons shown in Table $X$, shows that the impurities were about the same. Also, the impurities in the buttons produced by the runs to which metal was added are about the same os the impurities in the normal production buttons which were produced at the time this study was made.

Based on this information, it can be said that the metal recovered from low yield reduction slags can be processed by adding it to a normal reduction charge. It can also be stated that the addition of this recovered metal will not adversely affect the reduction yield, button purity, or the formation of the button, as long as the metal is not placed in the bottom of the crucible.

TABLE $X$

REDUCTION AND PURITY DATA ON PROCESSING OF RECOVERED PLUTONIUM METAL

Run No.

Weight of $\mathrm{PuF}_{4}$ in Charge, grams

Weight of $\mathrm{Pu}_{\mathrm{u}}$ in Charge, grams

Weight of metal added, grams

Location of metal

Button weight, grams

Reported yield, ${ }^{*}$. percent

Heoting time, min.

Button impurities, ppm

$\begin{array}{lr}\mathrm{Al} & 47 \\ \mathrm{Ca} & 500 \\ \mathrm{Cr} & 99 \\ \mathrm{Fe} & 315 \\ \mathrm{Mg} & 80 \\ \mathrm{Nl} & 127\end{array}$

1

2171

1650

$-$

$-$

1616

97.9

50

47

500

99

80

127

2
2171
1650
213
$1 / 4$ up from
bottom of
crucible
1804
96.8
32

39

20

128

285

60

71

3
2171
1650
214
on bottom
of crucible
1830
98.2
32
60
20
86
325
50
121

5

2171

1650

220

in middle

of charge

1838

98.3

49

29

1200

103

255

100

108

* Lab analyses of the $\mathrm{PuF}_{4}$ were not available, so the weight Pu charged and the yield are based on the assumption that the PuF 4 contained 76 percent $P$ II: 
RFP-728

16 
RFP-728

A P P E N D I X 
RFP-728 
TABLE XI

HIGH-SULFATE DATA FOR REDUCTION YIELD STUDY

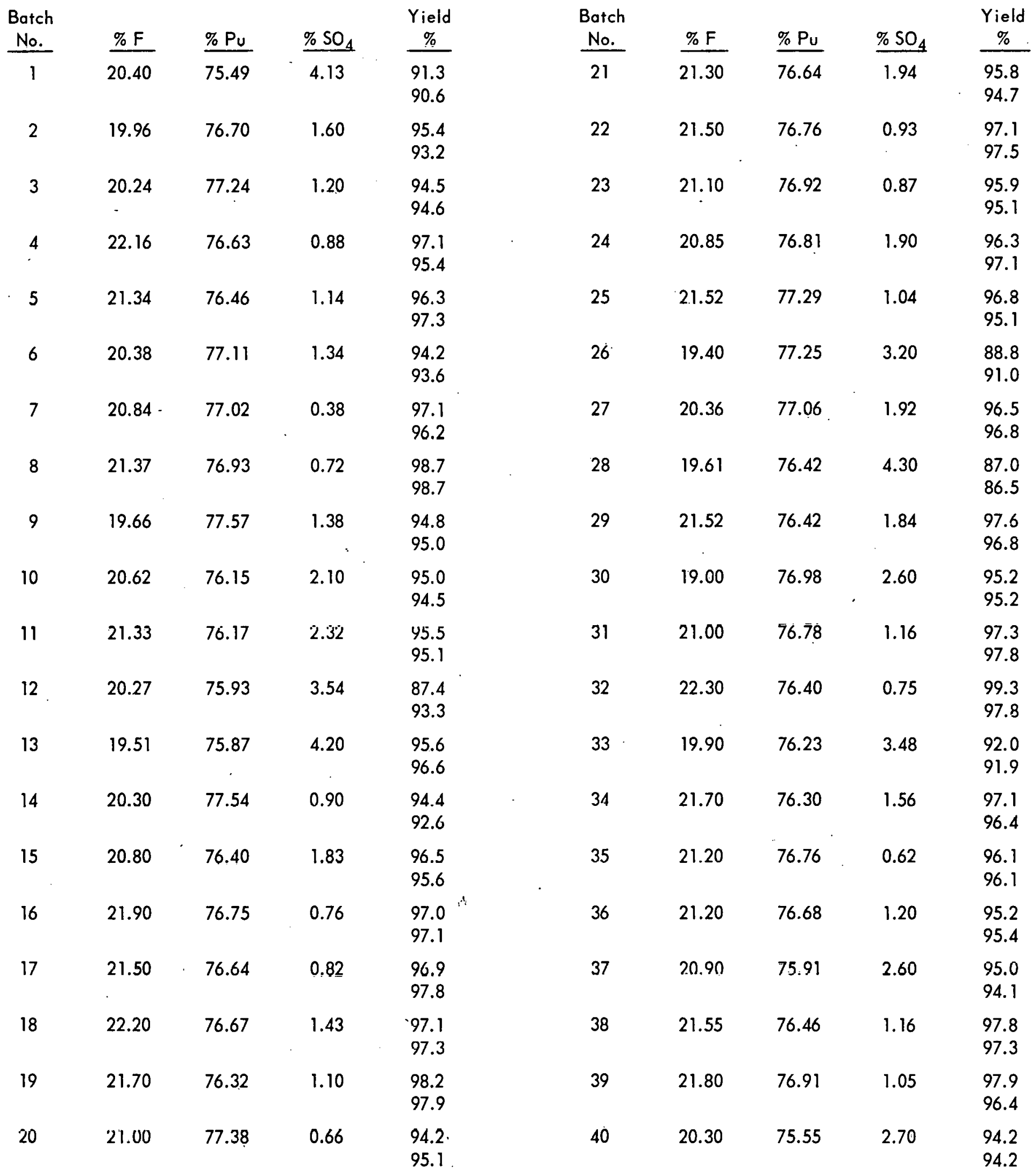


TABLE XII

LOW-SULFATE DATA FOR REDUCTION YIELD STUDY

\begin{tabular}{|c|c|c|c|c|c|c|c|c|c|}
\hline $\begin{array}{c}\text { Batch } \\
\text { No. } \\
\end{array}$ & $\% \mathrm{~F}$ & $\% \mathrm{Pu}$ & $\% \mathrm{SO}_{4}$ & $\begin{array}{c}\text { Yield } \\
\% \\
\end{array}$ & $\begin{array}{c}\text { Batch } \\
\text { No. } \\
\end{array}$ & $\% \mathrm{~F}$ & $\% \mathrm{Pu}$ & $\% \mathrm{SO}_{4}$ & $\begin{array}{c}\text { Yield } \\
\% \\
\end{array}$ \\
\hline 1 & 19.16 & 78.41 & $<0.20$ & 95.7 & 27 & 20.00 & 76.86 & 0.36 & 96.5 \\
\hline 2 & 19.64 & 77.84 & 0.68 & 93.8 & 28 & $20: 17$ & 76.71 & 0.38 & 96.6 \\
\hline 3 & 21.92 & 76.51 & 0.52 & 97.5 & 29 & 20.93 & 77.09 & $<0.20$ & 97.4 \\
\hline 4 & 21.30 & 77.00 & $<0.20$ & 97.7 & 30 & 20.47 & 77.15 & $<0.20$ & 97.5 \\
\hline 5 & 21.40 & 76.56 & $<0.20$ & 97.9 & 31 & 19.33 & 77.63 & 0.24 & 95.5 \\
\hline 6 & 18.85 & 78.56 & $<0.20$ & 93.4 & 32 & 19.99 & 77.60 & 0.36 & 96.5 \\
\hline 7 & 18.20 & 78.40 & $<0.20$ & 90.8 & 33 & 20.70 & 76.73 & 0.68 & 96.7 \\
\hline 8 & 19.40 & 78.15 & 0.20 & 92.0 & 34 & 20.71 & 77.12 & $<0.20$ & 97.7 \\
\hline 9 & 17.32 & 78.34 & $<0.20$ & 89.7 & 35 & 20.44 & 77.07 & 0.36 & 97.2 \\
\hline 10 & 17.25 & 79.35 & $<0.20$ & 86.4 & 36 & 20.40 & 76.98 & 0.25 & 96.9 \\
\hline 11 & 20.08 & 77.50 & 0.37 & 97.1 & 37 & 20.21 & 77.35 & 0.48 & 95.7 \\
\hline 12 & 20.74 & 76.96 & 0.88 & 97.7 & 38 & 20.23 & 77.28 & $<0.20$ & 97.6 \\
\hline 13 & 22.87 & 75.93 & 0.34 & 100 & 39 & 20.78 & 77.09 & $<0.20$ & 97.4 \\
\hline 14 & 22.80 & 75.92 & 0.25 & 100 & 40 & 17.90 & 77.38 & 0.75 & 77.7 \\
\hline 15 & 22.00 & 75.92 & $<0.20$ & 95.6 & 41 & 18.90 & 78.15 & $<0.20$ & 92.7 \\
\hline 16 & 18.70 & 77.80 & 0.35 & 93.2 & 42 & 19.00 & 77.49 & 0.58 & 93.9 \\
\hline 17 & 19.00 & 78.00 & 0.55 & 97.3 & 43 & 18.80 & 78.00 & $<0.20$ & 83.5 \\
\hline 18 & 20.62 & 77.53 & 0.50 & 96.0 & 44 & 21.10 & 77.35 & 0.46 & 96.1 \\
\hline 19 & 22.30 & 76.52 & 0.20 & 98.1 & 45 & 19.84 & 77.46 & $<0.20$ & 90.7 \\
\hline 20 & 21.90 & 76.75 & $<0.20$ & 96.3 & 46 & 19.30 & 77.55 & 0.36 & 97.2 \\
\hline 21 & 20.40 & 77.37 & $<0.20$ & 96.3 & 47 & 19.00 & 77.80 & $<0.20$ & 95.1 \\
\hline 22 & 20.20 & 77.15 & 0.36 & 96.9 & 48 & $20: 70$ & 76.90 & $<0.20$ & 97.7 \\
\hline 23 & 20.30 & 77.19 & $<0.20$ & 97.1 & 49 & 18.7 & 78.10 & $<0.20$ & 92.7 \\
\hline 24 & 19.70 & 77.44 & $<0.20$ & 96.7 & 50 & 20.80 & 77.50 & $<0.20$ & 97.0 \\
\hline 25 & 17.05 & 79.50 & 0.32 & 77.6 & 51 & 20.97 & 76.90 & $<0.20$ & 98.0 \\
\hline 26 & 17.34 & 79.15 & 0.37 & 84.6 & 52 & 22.11 & 76.50 & $<0.20$ & 97.4 \\
\hline
\end{tabular}

